\title{
Dendritic cells in the periphery control antigen-specific natural and induced regulatory T cells
}

\section{Sayuri Yamazaki * and Akimichi Morita}

Department of Geriatric and Environmental Dermatology, Graduate School of Medical Sciences, Nagoya City University, Nagoya, Japan

\section{Edited by:}

Eyad Elkord, United Arab Emirates University, UAE; University of Salford and University of Manchester, UK

\section{Reviewed by:}

Masahide Tone, Cedars-Sinai Medical Center, USA

Kristin Tarbell, NIDDK/NIH, USA

Hans Acha-Orbea, CIIL, Switzerland

\section{*Correspondence:}

Sayuri Yamazaki, Department of

Geriatric and Environmental

Dermatology, Graduate School of

Medical Sciences, Nagoya City

University, 1-Kawasumi, Mizuho-cho,

Mizuho-ku, Nagoya 467-8601, Japan

e-mail:yamazas@

med.nagoya-cu.ac.jp
Dendritic cells (DCs) are specialized antigen-presenting cells that regulate both immunity and tolerance. DCs in the periphery play a key role in expanding naturally occurring Foxp3 ${ }^{+}$ $\mathrm{CD}^{2} 5^{+} \mathrm{CD}^{+}{ }^{+}$regulatory T cells (Natural T-regs) and inducing Foxp3 expression (Induced T-regs) in Foxp3 ${ }^{-} \mathrm{CD}^{+} \mathrm{T}$ cells. DCs are phenotypically and functionally heterogeneous, and further classified into several subsets depending on distinct marker expression and their location. Recent findings indicate the presence of specialized DC subsets that act to expand Natural T-regs or induce Foxp3 ${ }^{+}$T-regs from Foxp3- ${ }^{-} D 4^{+} \mathrm{T}$ cells. For example, two major subsets of DCs in lymphoid organs act differentially in inducing Foxp3 $3^{+}$-regs from Foxp3 ${ }^{-}$cells or expanding Natural T-regs with model-antigen delivery by anti-DC subset monoclonal antibodies in vivo. Furthermore, DCs expressing CD103 in the intestine induce Foxp3 ${ }^{+}$T-regs from Foxp3 ${ }^{-}$CD4 ${ }^{+} T$ cells with endogenous TGF- $\beta$ and retinoic acid. In addition, antigen-presenting DCs have a capacity to generate Foxp3 ${ }^{+}$T-regs in the oral cavity where many antigens and commensals exist, similar to intestine and skin. In skin and skin-draining lymph nodes, at least six DC subsets have been identified, suggesting a complex DC-T-reg network. Here, we will review the specific activity of DCs in expanding Natural T-regs and inducing Foxp3 ${ }^{+}$T-regs from Foxp3 $3^{-}$precursors, and further discuss the critical function of DCs in maintaining tolerance at various locations including skin and oral cavity.

Keywords: dendritic cells, subset, Foxp3, antigen, tolerance

\section{INTRODUCTION}

Ralph Steinman and Zanvil Cohn discovered dendritic cells (DCs) in 1973. DCs have been shown to play a key role in the immune system to link innate and adaptive immunity (Steinman, 2012), a finding that won the Nobel Prize in 2011. DCs not only activate the immune system, but also participate in maintaining immunological-self tolerance (Steinman et al., 2003). DCs in the periphery actively induce tolerance when self-antigens are presented in the steady state (Hawiger et al., 2001; Bonifaz et al., 2002). In addition, DCs are critical antigen-presenting cells to regulate Foxp $3^{+} \mathrm{CD} 25^{+} \mathrm{CD} 4^{+}$regulatory T cells (T-regs) in the periphery (Yamazaki et al., 2006a; Yamazaki and Steinman, 2009).

T-regs are currently divided into thymic-derived Natural T-regs and peripheral Induced T-regs (Abbas et al., 2013). Recent findings have shown that Natural T-regs and Induced T-regs may be functionally and epigenetically different (Josefowicz et al., 2012; Ohkura et al., 2012; Samstein et al., 2012). The recent proposal of the nomenclature for T-regs recommends that " $\mathrm{tT}$-reg (thymusderived T-reg)" and "pT-reg (peripheral induced T-reg)" should be used instead of Natural T-regs and Induced T-regs (Abbas et al., 2013). The title of the Research Topics of Frontier Immunology is "Natural T-reg vs. Induced T-reg," therefore, we use the term "Natural T-reg" and "Induced T-reg" in this review. The two types of T-regs appear indistinguishable on the surface, but the expression of Neuropilin can distinguish Natural T-regs and Induced T-regs in mice but not in humans (Milpied et al., 2009; Weiss et al., 2012;
Yadav et al., 2012). Helios may be another marker for thymicderived T-regs (Thornton et al., 2010), but can be expressed on Induced T-regs in some conditions (Akimova et al., 2011; Gottschalk et al., 2012). In most literature, Natural T-regs may be the mixture of thymic-derived T-regs and peripheral induced T-reg because the T-regs were purified from spleen and lymph nodes, and Helios and Neuropilin were not investigated. If $\mathrm{CD} 4^{+}$ transgenic mice with $\mathrm{RAG}^{-/-}$background such as OT II RAG ${ }^{-1-}$ mice are used in the literature, the T-regs should be peripheral induced T-regs because those mice lack Foxp $3^{+}$T-regs (Itoh et al., 1999).

In the current review, we have focused on the roles of DCs in expanding antigen-specific Natural T-regs and inducing antigenspecific Foxp $3^{+}$T-regs (Induced T-regs) from Foxp3 ${ }^{-} \mathrm{CD}^{+}$ $\mathrm{T}$ cells. Recent studies indicate that DCs in different location have distinct subsets for expanding Natural T-regs and generating Induced T-regs.

\section{THYMIC-DERIVED NATURAL T-REGS ARE ANERGIC, BUT CAN BE EXPANDED BY ANTIGEN-PRESENTING DCS}

Sakaguchi et al. (1995) investigated autoimmune diseases induced by neonatal thymectomy, and discovered that a subpopulation of peripheral $\mathrm{CD} 4^{+} \mathrm{T}$ cells that express IL-2 receptor- $\alpha(\mathrm{CD} 25)$ derived from the thymus play a regulatory role in maintaining immunological-self tolerance (Asano et al., 1996). Their striking finding was that $\mathrm{CD} 25^{+} \mathrm{CD} 4^{+}$regulatory $\mathrm{T}$ cells exist in normal 
naïve $\mathrm{CD} 4^{+} \mathrm{T}$ cell population in the periphery with no immunization in mice. Subsequently, the groups of Shevach and Sakaguchi simultaneously reported one of the most prominent characteristics of $\mathrm{CD} 25^{+} \mathrm{CD} 4{ }^{+}$T-regs, specifically, " $\mathrm{CD} 25^{+} \mathrm{CD} 4{ }^{+} \mathrm{T}$-regs are anergic and suppressive upon T cell-receptor (TCR) stimulation with splenic antigen-presenting cells in vitro" (Takahashi et al., 1998; Thornton and Shevach, 1998). Thymic CD $25^{+} \mathrm{CD} 4{ }^{+} \mathrm{CD} 8^{-}$ $\mathrm{T}$ cells were additionally shown to be anergic and suppressive (Itoh et al., 1999). Therefore, at that time, thymic-derived Natural T-regs were considered non-proliferative and tough to expand, which posed a major limitation, as considerable numbers of $\mathrm{CD} 25^{+} \mathrm{CD} 4^{+}$T-regs are required to develop new treatments for autoimmunity.

Subsequently, we and others showed that $\mathrm{CD} 25^{+} \mathrm{CD} 4^{+}$Natural T-regs can be expanded, even without exogenous IL-2, when DCs are used as antigen-presenting cells (Yamazaki et al., 2003; Fehervari and Sakaguchi, 2004). According to the recent proposal of the nomenclature for T-regs (Abbas et al., 2013), these $\mathrm{CD} 25^{+} \mathrm{CD} 4^{+}$T-regs that we used in our experiments may be mixture of thymic-derived T-regs and peripheral induced $\mathrm{T}$ reg. Both $\mathrm{CD} 25^{+} \mathrm{CD} 4^{+}$T-regs in the periphery and thymic $\mathrm{CD} 25^{+} \mathrm{CD}^{+}{ }^{+} \mathrm{CD} 8{ }^{-} \mathrm{T}$ cells produced a small amount of IL- 2 following stimulation with antigen-presenting DCs (Yamazaki et al., 2003; Fehervari and Sakaguchi, 2004). Moreover, expansion of $\mathrm{CD} 25^{+} \mathrm{CD} 4^{+}$T-regs was partially dependent on the expression of CD86 and CD80 on DCs and IL-2 (Yamazaki et al., 2003). IL-2 is important for T-reg function and survival (Malek et al., 2002; Bayer et al., 2005; Setoguchi et al., 2005). Importantly, further investigations showed that the expanded Natural T-regs by antigen-presenting DCs suppress type-1 diabetes in NOD mice (Tarbell et al., 2004) and graft-versus-host diseases (GVHD) in an antigen-specific manner (Yamazaki et al., 2006b).

\section{POSSIBLE ROLE OF MONOCYTE-DERIVED DCs IN EXPANDING NATURAL T-REGS DURING INFLAMMATION}

Examination of several types of antigen-presenting cells, including resident classical DCs, for Natural T-reg expansion ability, revealed that lipopolysaccharide (LPS)-stimulated mature bone-marrowderived DCs (BM-DCs) and lymph node DCs from complete Freund's adjuvant (CFA)-treated mice exhibit the highest Natural T-reg expansion activity (Yamazaki et al., 2003).

Recent studies demonstrated that DC-SIGN/CD209a ${ }^{+}$ monocyte-derived DCs are recruited upon LPS injection, and accumulated in the $\mathrm{T}$ cell area of skin-draining lymph nodes (Cheong et al., 2010). DC-SIGN/CD209a ${ }^{+}$monocyte-derived DCs were as functionally active as resident classical DCs when tested for capture of antigen and presentation ability to MHC class I and class II to stimulate effector T cells. Specifically, DCSIGN/CD209a ${ }^{+}$cells were recruited from blood monocytes in a toll-like receptor (TLR)-4-, CD14-, and TRIF-dependent manner (Cheong et al., 2010). CFA contains mycobacterium tuberculosis, which can stimulate TLR-4 (Kleinnijenhuis et al., 2011).

We propose that DC-SIGN/CD209a ${ }^{+}$monocyte-derived DCs expand not only effector $\mathrm{T}$ cells, but also Natural T-regs for the regulation of inflammation (Figure 1). This would indicate that inflammation induced by microbe signals induces DC maturation and activates effector cells, but simultaneously induces
Natural T-reg expansion to control the inflammatory process (Figure 1). While inflammation is induced by several stimuli, it remains to be established whether other stimuli except TLR-4 can generate DC-SIGN/CD209a ${ }^{+}$monocyte-derived DCs in vivo. Further studies are necessary to investigate the signals that recruit DC-SIGN/CD209a ${ }^{+}$monocyte-derived DCs.

The finding that Natural T-regs can be expanded by mature DCs during inflammation is intriguing. The next issue to resolve is whether Induced T-regs are also generated during inflammation that have a role in controlling the inflammatory process. As we discussed below, Induced T-regs are generated via signaling through TGF- $\beta$ LPS-matured BM-DCs are active in inducing Foxp $3^{+}$Tregs from Foxp $3^{-} \mathrm{CD} 4^{+} \mathrm{T}$ cells in the presence of active TGF- $\beta$ (Yamazaki et al., 2007). TGF- $\beta$ is produced as an inactive latent complex from many cells, and activation is localized to sites where TGF- $\beta$ is released from latency (Li and Flavell, 2008; Yang et al., 2012). TGF- $\beta$ has been shown to be activated by $\alpha_{v} \beta_{8}$ integrin on the DC surface (Travis et al., 2007). Therefore, it is possible that Induced T-regs are generated by mature DCs that participate in controlling the inflammation as well as Natural T-regs, as long as TGF- $\beta$ is provided from other cells (Figure 1).

\section{DCs ARE PROFESSIONAL ANTIGEN-PRESENTING CELLS THAT INDUCE FOXP3 EXPRESSION FROM FOXP3- CD4+ T CELLS IN THE PRESENCE OF TGF- $\beta$}

Foxp3 is an established critical transcription factor for T-reg development and function (Fontenot et al., 2003; Hori et al., 2003; Khattri et al., 2003). In addition to thymic-derived Natural Foxp $3^{+}$ T-regs, Foxp $3^{+}$T-regs are induced from Foxp $3^{-} \mathrm{CD}^{+} \mathrm{T}$ cells in the periphery, designated "Induced T-regs," "Adaptive T-regs," or pT-regs (Abbas et al., 2013). The finding that Foxp3 ${ }^{+}$T-regs are induced from Foxp $3^{-} \mathrm{CD} 25^{-} \mathrm{CD} 4{ }^{+} \mathrm{T}$ cells with TGF- $\beta$ in the periphery was initially reported by Chen et al. (2003).

To investigate whether DCs play a role in the induction of Foxp $3^{+}$T-regs from Foxp $3^{-} \mathrm{CD}^{+}{ }^{+} \mathrm{T}$ precursors, using OVA $\mathrm{CD}^{+}$T-cell-receptor transgenic mice with $\mathrm{RAG}^{-/-}$background, we compared the Foxp3 induction activities of spleen CD $11 c^{+}$DCs with DC-depleted splenocytes (Yamazaki et al., 2007). Notably, lower numbers of DCs were able to induce more Foxp $3^{+}$T-regs with smaller doses of peptide antigens in the presence of TGF- $\beta$ (Yamazaki et al., 2007). The T-regs induced by antigen-presenting DCs were suppressive in vitro and in vivo (Yamazaki et al., 2007). DCs were also able to induce Foxp $3^{+}$T-reg from wild-type polyclonal Foxp $3^{-} \mathrm{CD}^{+} \mathrm{T}$ precursors via allogeneic mixed leukocyte reactions. Allogeneic DCs expand functional Induced Foxp $3^{+}$ T-regs in the presence of with TGF- $\beta$ in vitro (unpublished data).

The collective findings indicate that DCs require only a small amount of antigen to induce Foxp $3^{+}$T-regs if TGF- $\beta$ is provided from the environment, supporting the theory that DCs are the professional antigen-presenting cells to induce Foxp $3^{+}$T-regs from Foxp $3^{-}$precursors in the periphery.

\section{THE FOXP3 ${ }^{+}$T-REG NUMBER IS REGULATED BY DCs IN VIVO}

In keeping with the above findings that DCs expand Natural Tregs and induce T-regs from Foxp $3^{-} \mathrm{T}$ cells, the numbers of DCs, and Foxp3 ${ }^{+}$T-regs in vivo correlate with each other. GM-CSF, a key cytokine in DC generation (Caux et al., 1992; Inaba et al., 


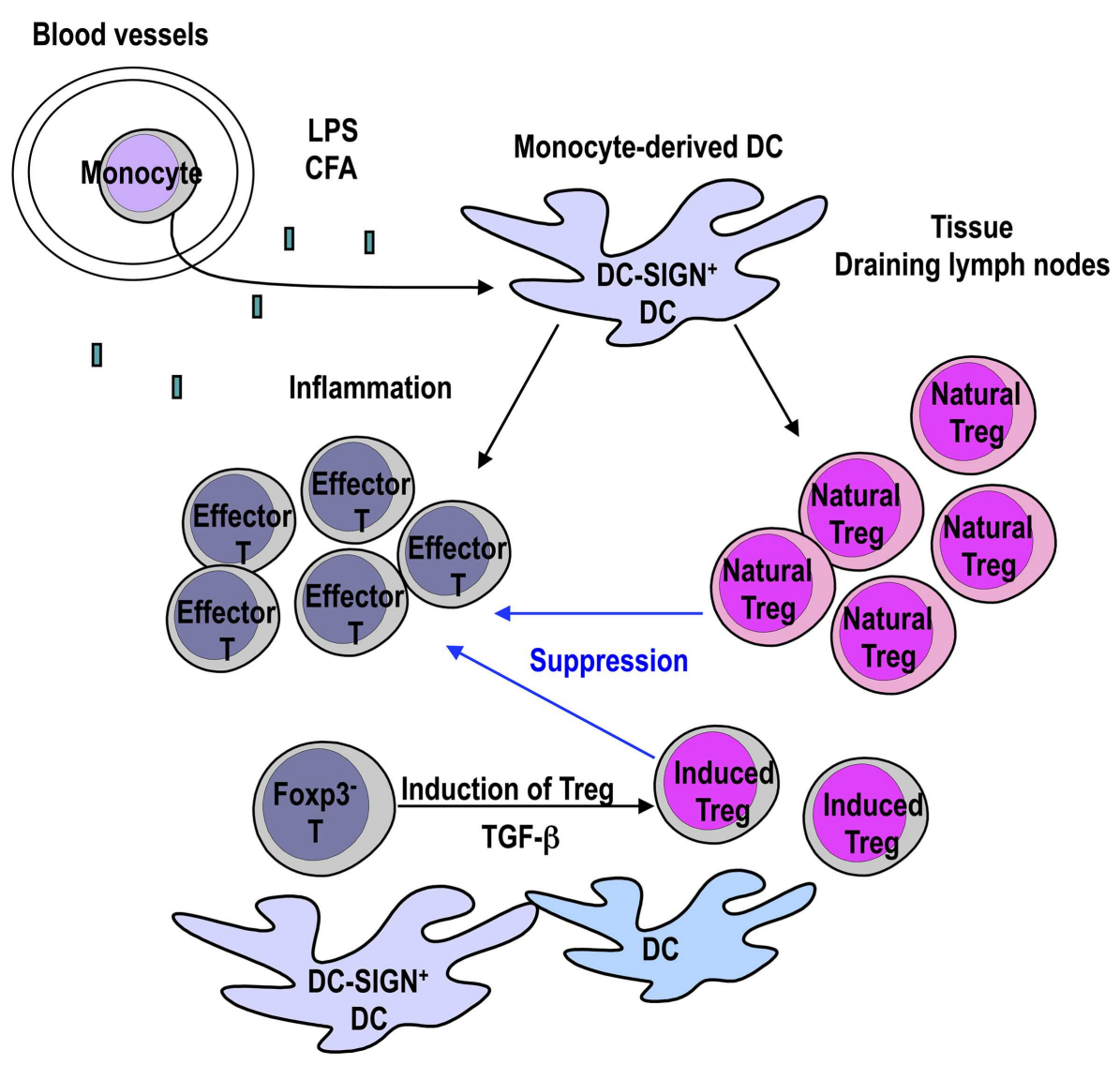

FIGURE 1 | Monocyte-derived DCs expand Foxp3 ${ }^{+}$T-regs to control inflammation. DC-SIGN/CD209a ${ }^{+}$monocyte-derived DCs are recruited to the site of inflammation by TLR-4 ligands such as LPS or CFA. The mature monocyte-derived DCs present antigens to not only effector T cells but also Natural T-regs. LPS-matured DCs can expand functional Natural T-regs
(Yamazaki et al., 2003). If TGF- $\beta$ is provided from other cells, mature DCs in the inflammatory site can stimulate the generation of Induced T-regs from Foxp3- ${ }^{-} D 4^{+}$T cells in the presence of antigen (Yamazaki et al., 2007). Expanded Natural T-regs and Induced T-regs may play a role in controlling inflammation.
1992; van de Laar et al., 2012), was shown to promote Natural T-reg expansion via DC generation and prevent type 1 diabetes in NOD mice (Gaudreau et al., 2007). Similarly, repetitive injection of Fms-like tyrosine kinase 3 ligand (FLT3L), another important cytokine for DC development (Maraskovsky et al., 1996; Waskow et al., 2008), induced expansion of Natural T-regs (Swee et al., 2009). Moreover, in vivo ablation of Foxp3 $3^{+}$T-regs in Foxp3diphtheria toxin (DT) receptor (Foxp3-DTR) mice led to increased DC number in vivo (Kim et al., 2007). Division of DC precursors is controlled by Foxp3 ${ }^{+}$T-regs (Liu et al., 2009), and the numbers of DCs are directly correlated with the Foxp $3^{+}$T-reg number in vivo (Darrasse-Jeze et al., 2009). Notably, Foxp3 $3^{+}$T-reg number was reduced in CD11c-DT receptor (CD11c-DTR) bone marrow chimera mice after depletion of CD11c ${ }^{+}$DCs (Darrasse-Jeze et al., 2009). Therefore, Foxp $3^{+}$T-regs and DCs appear to regulate each other in vivo.

However, constitutive DC-depleted mice contain normal level of Foxp3 ${ }^{+}$T-regs in the thymus and periphery (Birnberg et al., 2008; Ohnmacht et al., 2009). Birnberg et al. (2008) crossed CD11c-Cre BAC transgenic mice with those harboring a conditional diphtheria toxin A (DTA) transgene in the constitutively active Rosa26 locus (CD11c-DTA mice). CD11c-DTA mice constitutively lacked classical DCs, but contained spared amount of plasmacytoid DCs (pDCs) and epidermal Langerhans' cells (LCs). These mice developed myeloproliferative diseases, but contained normal Foxp $3^{+}$T-reg numbers in thymus and spleen (Birnberg et al., 2008). Foxp $3^{+}$T-regs from CD11c-DTA mice constitutively lacking classical DCs exerted suppressive effects in vitro (Birnberg et al., 2008). Subsequently, Ohnmacht et al. (2009) developed similar CD11c-DTA mice with constitutive loss of all classical DCs, pDCs, and LCs. In their mice, both intrathymic Natural T-reg development and peripheral Foxp $3^{+}$T-reg induction were normal, but Th1 and Th17 cells were spontaneously increased (Ohnmacht et al., 2009).

Thus, there is a discrepancy in the number of Foxp $3^{+} \mathrm{T}$ regs between CD11c-DT receptor (CD11c-DTR) bone marrow chimera mice (Darrasse-Jeze et al., 2009) and constitutive DCdepleted mice (Birnberg et al., 2008; Ohnmacht et al., 2009), in which may be attributed to the differences between acute and chronic DC depletion. In the case of acute DC depletion with DT, DC activity in maintaining Foxp $3^{+}$T-regs may be easy to detect. In contrast, upon constitutive deletion of DCs, antigen-presenting 
cells other than DC may be able to compensate and rescue the development and homeostasis of Foxp $3^{+}$T-regs in the periphery. Alternatively, in the case of Birngerb's mice, it is possible that pDCs and LCs are sufficiently active in maintaining the Foxp $3^{+}$T-regs in the periphery.

Taken together, the results indicate that DCs regulate the numbers of Foxp $3^{+}$T-regs in vivo. It is possible that DCs regulate the numbers of Foxp $3^{+}$T-regs in vivo may be dependent on IL2, which is an important cytokine both for Natural T-regs and Induced T-regs (Malek et al., 2002; Bayer et al., 2005; Setoguchi et al., 2005; Davidson et al., 2007). DCs has been shown to produce IL-2 upon LPS stimulation (Granucci et al., 2001). Treatment of anti-IL-2 antibody reduces the numbers of T-regs in vivo and main source of IL-2 was T cells (Setoguchi et al., 2005). However, we cannot deny the possibility that IL-2 from DCs have a role in regulating the numbers of Foxp $3^{+}$T-regs especially in the inflammatory condition.

The types of T-reg (Natural or Induced) regulated by DCs in vivo were the next focus of discussion. In FLT3-treated mice, adoptively transferred Foxp $3^{+} \mathrm{T}$ cells were expanded, but not converted into Foxp3 ${ }^{+}$T-regs (Darrasse-Jeze et al., 2009; Swee et al., 2009). Thymectomy prior to FLT-3 treatment did not affect the observed increase of Foxp $3^{+}$T-regs. Accordingly, it is suggested that the thymic output of Foxp $3^{+}$T-reg does not contribute to the increase of T-reg by FLT-3 (Swee et al., 2009). GM-CSF treatment induced expansion of Natural T-regs, but no conversion of Foxp3 ${ }^{-}$T cells into Foxp3 ${ }^{+}$T-regs in vitro (Zou et al., 2010). It appears that DCs expanded by FLT-3 or GM-CSF in vivo regulate Natural, rather than Induced T-regs.

In experiments where polyclonal Foxp $3^{-} \mathrm{CD} 4^{+} \mathrm{T}$ cells were used for the adoptive transfer in these reports, no cognate antigen was employed (Darrasse-Jeze et al., 2009; Swee et al., 2009; Zou et al., 2010). TCR repertoires from Natural T-regs are reported to be more skewed to self antigens (Jordan et al., 2001; Hsieh et al., 2004, 2006; Sakaguchi et al., 2008). Therefore, it is possible that TCR stimulation was insufficient to induce Foxp3 in adoptive transferred Foxp $3^{-} \mathrm{CD}^{+} \mathrm{T}$ cells from wild-type polyclonal mice in these reports. Peripheral induction of Foxp3 appears to favor suboptimal TCR stimulation (Kretschmer et al., 2005; Gottschalk et al., 2010), however, TCR stimulation is required for induction of Foxp3 (Ohkura et al., 2012). Therefore, we cannot discount the possibility that the Induced Foxp $3^{+}$T-regs are regulated by DCs in vivo. For example, en earlier study by Huang et al. (2010) showed that in vivo injection of IL-10-treated BMDCs promoted the conversion of Foxp $3^{-} \mathrm{CD} 25^{-} \mathrm{CD} 4^{+} \mathrm{T}$ cells into Foxp $3^{+} \mathrm{CD} 25^{+} \mathrm{CD} 4{ }^{+}$T-regs and prevents asthma attack. In this case, IL-10-treated BM-DCs may regulate Induced Foxp $3^{+}$T-regs.

\section{SPECIALIZED DC SUBSETS MAY EXPAND NATURAL T-REGS} AND INDUCED T-REGS

The next issue addressed is identifying the DC subsets that regulate Foxp $3^{+}$T-regs in vivo. DCs constitute several subsets with distinct functions (Heath and Carbone, 2009; Hashimoto et al., 2011; Belz and Nutt, 2012; Steinman, 2012). Murine classical spleen DCs are divided into two major subsets, i.e., $\mathrm{CD} 8^{+} \mathrm{DEC} 205^{+}$ and $\mathrm{CD}^{-}{ }^{-}$DCIR2 $^{+}$(Dudziak et al., 2007). Accumulating evidence indicates that antigen delivery to $\mathrm{CD} 8{ }^{+} \mathrm{DEC} 205 \mathrm{DCs}$ by anti-DEC205 monoclonal antibody induces Foxp3 ${ }^{+}$T-regs from Foxp3 ${ }^{-}$T cells in vivo (Mahnke et al., 2003; Kretschmer et al., 2005; Yamazaki et al., 2008). Moreover, Natural T-regs are expanded by $\mathrm{CD}^{-}{ }^{-} \mathrm{DCIR}^{+}{ }^{+}$DCs via model-antigen delivery by anti-DCIR2 monoclonal antibody in vivo (Yamazaki et al., 2008).

TGF- $\beta$ plays an important role in the mechanisms of induction of Foxp $3^{+}$T-regs from Foxp $3^{-} \mathrm{T}$ precursors via in vivo antigen targeting to DCs (Kretschmer et al., 2005). When the protein level of TGF- $\beta$ production was compared, DEC $205^{+} \mathrm{CD} 8^{+} \mathrm{DCs}$ produced more TGF- $\beta$ than $\mathrm{CD} 8^{-}$DCIR2 ${ }^{+}$DCs in the steady state (Yamazaki et al., 2008). DEC $205^{+} \mathrm{CD} 8^{+}$DCs induced Foxp $3^{+}$ T-regs from Foxp $3^{-} \mathrm{CD} 4^{+} \mathrm{T}$ cells without exogenous TGF$\beta$. The induction of Foxp $3^{+}$T-regs by $\mathrm{DEC} 205^{+} \mathrm{CD} 8^{+} \mathrm{DCs}$ was blocked by anti-TGF- $\beta$ neutralizing antibody. Importantly, DEC205 ${ }^{+} \mathrm{CD}^{+}$DCs matured with poly:IC, a TLR-3 ligand, produced less TGF- $\beta$ than immature DEC $205^{+} \mathrm{CD} 8^{+}$DCs DCs from steady state (Yamazaki et al., 2008). CD8 ${ }^{-}$DCIR2 ${ }^{+}$DCs were more potent inducers of Foxp $3^{+}$T-regs after addition of TGF- $\beta$ into the culture, indicating that CD8 ${ }^{-}$DCIR2 $^{+}$DCs can use TGF- $\beta$ provided from other cells (Yamazaki et al., 2008) (Table 1).

Recent studies in DEC205 conditional knockout mice (DEC205 Dt/DT) (Fukaya et al., 2012) support the findings that DEC205 ${ }^{+} \mathrm{CD}^{+}{ }^{+}$DCs induce Foxp $3^{+}$T-regs from Foxp $3^{-}$cells and $\mathrm{CD}^{-}{ }^{-}$DCIR2 $^{+}$DCs expand existing Natural T-regs (Yamazaki et al., 2008). Fukaya et al. (2012) used bone marrow chimeric mice reconstituted with bone marrow from DEC205 Dt/DT mice, lacking DEC $205^{+} \mathrm{CD} 8{ }^{+} \mathrm{DC}$ via DT injection. DEC205 ${ }^{+} \mathrm{DC}$ s were depleted for about 7 days after DT injection, with a complementary increase in $\mathrm{CD}^{-}$DCs. In DEC205 ${ }^{+}$DC-depleted mice, peripheral Foxp $3^{+}$T-reg numbers were increased, suggesting that existing Natural T-regs in the periphery are expanded by complementally increased CD8 ${ }^{-}$DCs. Upon transfer of Foxp3 $3^{-} \mathrm{CD}^{+}{ }^{+} \mathrm{OVA}$ transgenic OT II T cells into the chimeric DEC $205^{+}$DC-depleted mice, antigen-specific induction of Foxp $3^{+}$T-regs from Foxp $3^{-}$ $\mathrm{CD}^{+} \mathrm{T}$ cells was impaired (Fukaya et al., 2012). Therefore, DEC $205^{+} \mathrm{CD}^{+}$DCs appear critical for the induction of Foxp $3^{+}$ T-regs from Foxp $3^{-} \mathrm{CD} 4^{+} \mathrm{T}$ cells in the periphery. Notably, epidermal host-derived LCs remained in chimeric DEC205 ${ }^{+}$

Table 1 | Foxp3 ${ }^{+}$T-regs and classical spleen DCs in the steady state.

\begin{tabular}{|c|c|c|c|}
\hline & $\mathrm{CD}^{+}{ }^{+} \mathrm{DEC} 205^{+} \mathrm{DCs}$ & $\mathrm{CD8}^{-} \mathrm{DCIR2}^{+} \mathrm{DCs}$ & Reference \\
\hline In vivo OVA targeting & Induce T-regs & Expand natural T-regs & Yamazaki et al. (2008) \\
\hline TGF- $\beta$ production & High in steady state & Low & Yamazaki et al. (2008) \\
\hline Other known feature & $\begin{array}{l}\text { Cross presentation, excel in } \mathrm{MHC} \mathrm{I} \\
\text { presentation }\end{array}$ & Excel in MHC II presentation & $\begin{array}{l}\text { Dudziak et al. (2007), Kamphorst } \\
\text { et al. (2010) }\end{array}$ \\
\hline
\end{tabular}


DC-depleted mice, since LCs are radioresistant. Based on these results, DEC205 ${ }^{+}$DCs other than LCs (mainly $\mathrm{CD}^{+}{ }^{+} \mathrm{DEC} 205^{+}$ DCs), have greater regulatory effects on the Foxp $3^{+}$T-reg numbers in the periphery (Fukaya et al., 2012).

\section{IN VIVO ANTIGEN-TARGETING DELIVERY INDUCES FUNCTIONAL FOXP3 ${ }^{+}$T-REGS IN TRANSGENIC TCR}

Regarding the suppressive function of Foxp $3^{+}$T-regs induced by antigen targeting to DCs in vivo, accumulating evidence has shown that antigen delivery to the DC subset suppresses experimental autoimmune encephalomyelitis (EAE) (Hawiger et al., 2004; Stern et al., 2010; Loschko et al., 2011; Idoyaga et al., 2013). Antigen delivery to not only DEC $205^{+} \mathrm{CD} 8^{+}$DCs but also Langerin ${ }^{+} \mathrm{DCs}$ and pDCs led to induction of Foxp $3^{+}$T regs and suppression of EAE (Loschko et al., 2011; Idoyaga et al., 2013). Some DEC205 ${ }^{+} \mathrm{CD}^{+}$ DCs express Langerin, and therefore, the targeting antigen to Langerin ${ }^{+}$DCs may represent targeting to DEC $205^{+} \mathrm{CD} 8^{+}$DCs. While induction of T-regs from Foxp $3^{-}$cells is reported as the main mechanism to suppress the autoimmunity via DC antigen delivery in these reports, it should be noted that in an in vivo protection assay of EAE, mice require injection with adjuvant CFA, which could expand Natural T-regs, as described above.

Another notable point is that these in vivo antigen delivery studies were mainly performed using transgenic mice, and therefore, the results may be artificial or specific to the experimental mice employed. In future immune therapy for autoimmunity, transplantation tolerance, and allergy, antigen targeting to DCs in vivo should be undertaken using polyclonal $\mathrm{T}$ cell repertoires. In this regard, it is very intriguing that continuous infusion of HY male peptide induced antigen-specific Foxp $3^{+}$T-regs in the wild-type naïve repertoire to suppress the male-graft rejection response (Verginis et al., 2008). Although subcutaneous infusion of peptide antigen by osmotic pumps was performed (Verginis et al., 2008) and not targeting antigen to DCs, it is possible that DEC205 ${ }^{+} \mathrm{CD}^{+}{ }^{+}$DCs pick up the infused peptide and present antigen to $\mathrm{T}$ cells. Moreover, it is important to ascertain whether antigen targeting to DCs with the polyclonal $\mathrm{T}$ cell repertoire in humans induces Foxp3 ${ }^{+}$T-regs. Targeting antigen to DCs via ASGPR in human induced IL-10 producing T-regs (Li et al., 2012). Further research on antigen delivery to DCs in vivo with a naïve repertoire in mice and humans is required.

\section{CD103+ $^{+}$Cs ARE SPECIALIZED DCs THAT INDUCE FOXP3+ T-REGS IN THE INTESTINE}

It is well established that specialized DC subsets induce Foxp $3^{+} \mathrm{T}-$ regs in the intestine. The groups of Belkaid and Powrie found that gut DCs expressing CD103, the $\alpha \mathrm{E} \beta 7$ integrin, induce Foxp $3^{+} \mathrm{T}$ regs using endogenous retinoic acid (RA) and TGF- $\beta$ (Coombes et al., 2007; Sun et al., 2007). RA is known to imprint T cells expressing CD103 with gut-homing instructions (Iwata et al., 2004). Furthermore, RA, a vitamin A metabolite, controls the Th17 and Foxp3 ${ }^{+}$T-reg balance (Mucida et al., 2007). Importantly, $\mathrm{CD}_{103^{+}} \mathrm{DCs}$ has retinoic acid dehydrogenase (RALDH) that activates RA (Coombes et al., 2007; Sun et al., 2007). RA suppresses the production of inflammatory cytokines and acts as a co-factor for TGF- $\beta$ to induce Foxp $3^{+}$T-regs (Hill et al., 2008).
Interestingly, $\mathrm{CD} 03^{+} \mathrm{DCs}$ are migratory DCs that carry antigens from the intestine to lymph nodes (Jaensson et al., 2008). Therefore, intestine-derived $\mathrm{CD}_{103}{ }^{+} \mathrm{DCs}$ present feeding antigens to induce Foxp $3^{+}$T-regs and play a key role in maintaining oral tolerance. The group of Honda showed that Foxp3 ${ }^{+}$T-regs in colon are possibly induced by commensal bacteria, Clostridium (Atarashi et al., 2011). Germ-free mice and antibiotics-treated mice had decreased numbers of Foxp $3^{+}$T-regs in colon, but increased or unchanged numbers of T-regs in small intestine. Clostridium-colonized gnotobiotic mice exhibited a robust accumulation of Foxp $3^{+}$T-regs in colon, but not in small intestine. Colonic epithelial cells stimulated with Clostridum produced TGF$\beta$ (Atarashi et al., 2011). Therefore, Foxp $3^{+}$T-regs are induced by Clostridium directly in the colon, but not in the small intestine. It is possible that Foxp $3^{+}$T-reg induction in the small intestine and colon may be regulated via different mechanisms.

\section{THE ROLE OF VITAMIN D IN INDUCTION OF FOXP3 ${ }^{+}$T-REGS BY DC SUBSETS}

Another intriguing question to solve was whether vitamin $\mathrm{D}_{3}$ generated skin facilitates Foxp $3^{+}$T-reg induction, in view of the finding that RA, the active metabolite of vitamin A, play a role in inducing Foxp $3^{+}$T-regs in the intestine. Vitamin $\mathrm{D}_{3}$ (cholecalciferol) is generated in the skin in response to sun exposure, and converted to active $1,25(\mathrm{OH})_{2} \mathrm{D}_{3}$ through an enzymatic cascade in the liver and kidney. Vitamin D controls not only calcium homeostasis but also the immune functions (Sigmundsdottir and Butcher, 2008; Baeke et al., 2010; Maruotti and Cantatore, 2010).

Active 1,25 $(\mathrm{OH})_{2} \mathrm{D}_{3}$ production is controlled by 25hydroxyvitamin $\mathrm{D}_{3}-1 \alpha$-hydroxylase $\left(25(\mathrm{OH}) \mathrm{D}_{3}-1 \alpha\right.$-hydroxylase $)$, the mitochondrial cytochrome $\mathrm{P} 450$ enzyme that catalyzes the conversion of $25(\mathrm{OH}) \mathrm{D}_{3}$. Synthesis of $1,25(\mathrm{OH})_{2} \mathrm{D}_{3}$ normally occurs in the kidney. However, it is reported that DCs participate in local production of active $1,25(\mathrm{OH})_{2} \mathrm{D}_{3}$ in an autocrine or paracrine manner (Fritsche et al., 2003). In experiments using human monocyte-derived DCs, they found that LPS-matured DCs actively produced $1,25(\mathrm{OH})_{2} \mathrm{D}_{3}$.

Sigmundsdottir et al. (2007) reported that the sun-light induced precursor, vitamin $\mathrm{D}_{3}$, is metabolized by DCs and presented as $1,25(\mathrm{OH})_{2} \mathrm{D}_{3}$ to responding $\mathrm{T}$ cells. The vitamin, $1,25(\mathrm{OH})_{2} \mathrm{D}_{3}$, induced T-cell expression of CCR10 and Tcell migration to the chemokine, CCL27. Human DCs express both 25- and 1-hydroxylase activities (CYP27A1 and CYP27B1). The group demonstrated that monocyte-derived DCs and skindraining lymph node DCs have the capacity to activate vitamin $D_{3}$. However, the type of DC subset activating vitamin $D_{3}$ remains unknown and should be an exciting focus of future research. Mouse T cells upregulate CCR10 and move by chemotaxis to CCL27 less efficiently than human T cells after treatment with 1,25 $(\mathrm{OH})_{2} \mathrm{D}_{3}$ (Sigmundsdottir et al., 2007; Sigmundsdottir and Butcher, 2008). Therefore, identification of the vitamin D-metabolizing DC subset that plays a role in inducing Foxp $3^{+}$ T-regs or expanding Natural T-regs using mice may be difficult.

Although the DC subsets metabolizing vitamin $\mathrm{D}_{3}$ have not been determined, vitamin $\mathrm{D}$ clearly play a role in Foxp3 ${ }^{+}$T-regs (Ghoreishi et al., 2009; Jeffery et al., 2009; Urry et al., 2012). For example, Jeffery et al. (2009) reported that human CD25- CD4 ${ }^{+}$ 
T cells are converted into CTLA $-4^{+}$Foxp $3^{+}$T-regs in the presence of mature DCs plus inactive $25(\mathrm{OH}) \mathrm{D}_{3}$. Based on this finding, it is proposed that mature DCs produce active $1,25(\mathrm{OH})_{2} \mathrm{D}_{3}$ and induce Foxp $3^{+}$T-regs from Foxp $3^{-}$cells. Urry et al. (2012) showed that human and murine Natural T-regs maintain Foxp3 expression and are expanded in the presence of active $1,25(\mathrm{OH})_{2} \mathrm{D}_{3}$, even with the absence of DCs in the culture. Therefore, it is possible that vitamin D play a role in the stimulation of both Natural T-regs and Induced T-regs.

\section{SKIN DC SUBSETS AND FOXP3+ T-REGS}

Dendritic cell subsets are more complex in skin and skin-draining LNs (Figure 2). Skin-resident DCs include epidermal Langerhans cells (LCs) and dermal DCs. Langerin (CD207) is a C-type lectin mainly expressed on mainly LCs. It was originally assumed that Langerin ${ }^{+}$dermal DCs constitute transit LCs from the epidermis to skin-draining lymph nodes, until a distinct population was identified (Bursch et al., 2007; Ginhoux et al., 2007; Poulin et al., 2007; Nagao et al., 2012). LCs are radioresistant and renew via in situ proliferation in the steady state (Merad et al., 2002; Poulin et al., 2007). Some precursors of LCs are recruited from monocytes to hair follicles after stress (Nagao et al., 2012). In contrast, Langerin ${ }^{+}$and Langerin ${ }^{-}$dermal DCs are constantly maintained by blood-borne radiosensitive bone marrow precursors (Bursch et al., 2007; Ginhoux et al., 2007; Poulin et al., 2007; Liu et al., 2009). Furthermore, recent reports indicate that dermal DCs are divided into three subsets: Langerin ${ }^{+}$ CD11b ${ }^{\text {low }}$, Langerin ${ }^{-} \mathrm{CD}_{11} \mathrm{~b}^{-}$, and Langerin ${ }^{-} \mathrm{CD}_{11 \mathrm{~b}}{ }^{+}$(Guilliams et al., 2010b; Henri et al., 2010). In these studies, half of the Langerin ${ }^{+} \mathrm{CD} 11 b^{\text {low }}$ dermal DCs appeared to express CD103, while the other half were devoid of CD103. Skin DCs constantly migrate to skin-draining lymph nodes and constitute migratory DC subsets. Therefore, in skin-draining lymph nodes, there are resident classical $\mathrm{CD}^{+}{ }^{+} \mathrm{DCs}, \mathrm{CD} 8^{-} \mathrm{DCs}$, pDCs, and migratory skin DCs, including LCs and three to four dermal DCs.

Accumulating evidence has shown that lymphoid tissueresident $\mathrm{CD}^{+}{ }^{+} \mathrm{DCs}$ and $\mathrm{CD} 103^{+}$DCs are members of the same subset (Ginhoux et al., 2009; Edelson et al., 2010). CD8 ${ }^{+}$DCs and $\mathrm{CD}_{103}{ }^{+}$DCs play specialized roles for cross-presentation (Bedoui et al., 2009), and their development is regulated by the same four transcription factors (Belz and Nutt, 2012). Lagnerin ${ }^{+}$CD103 ${ }^{+}$ DCs are specialized to cross-present antigens (Henri et al., 2010). Moreover, $\mathrm{CD} 103^{+}$DCs are considered migratory DCs (Huang et al., 2010). Some resident $\mathrm{CD}^{+} \mathrm{DCs}$ are known to express Langerin (Cheong et al., 2007). Malissen and colleagues proposed that the universal classification of DCs into five major subsets irrespective of tissues and species, specifically, monocytederived inflammatory DCs, LCs, pDCs, CD11b-type DCs, and CD8-type DCs (Guilliams et al., 2010b). Among these, CD11btype DCs are heterogeneous (Ginhoux et al., 2009). Notably, the gut $\mathrm{CD}_{103}{ }^{+} \mathrm{DCs}$ that induce Foxp $3^{+}$T-regs may be different from CD8-type DCs such as dermal Langerin ${ }^{+} \mathrm{CD}_{103}{ }^{+}$DCs because the gut $\mathrm{CD} 103^{+}$DCs express CD11b, whereas Langerin ${ }^{+} \mathrm{CD}_{103}{ }^{+} \mathrm{DCs}$ do not (Heath and Carbone, 2009). It is possible that the gut $\mathrm{CD}^{+}{ }^{+}$DC subset is one of CD11b-type DCs (Heath and Carbone, 2009).

According to this classification, migratory $\mathrm{CD}_{103}{ }^{+} \mathrm{DCs}$ and resident $\mathrm{CD}^{+}{ }^{+} \mathrm{DC}$ are Langerin ${ }^{ \pm}$and considered part of the same subset as CD8-type DCs. This theory is attractive since both migratory $\mathrm{CD} 103^{+} \mathrm{DCs}$ and resident $\mathrm{CD}^{+} \mathrm{DCs}$ are probably active in inducing Foxp3 ${ }^{+}$T-regs (Yamazaki et al., 2008; Idoyaga et al., 2013). Thus, another possible common feature of CD8-type DC may be Foxp $3^{+}$T-reg induction activity.

In view of the complex skin DC network, cross-talk between skin DC subsets and Foxp $3^{+}$T-regs may be also complex (Figure 2). Based on the universal classification system, $\mathrm{CD}_{103^{+}}$ Langerin ${ }^{+} \mathrm{CD}_{11 b^{\text {low }}}$ dermal DCs are apparently CD8-type DCs,

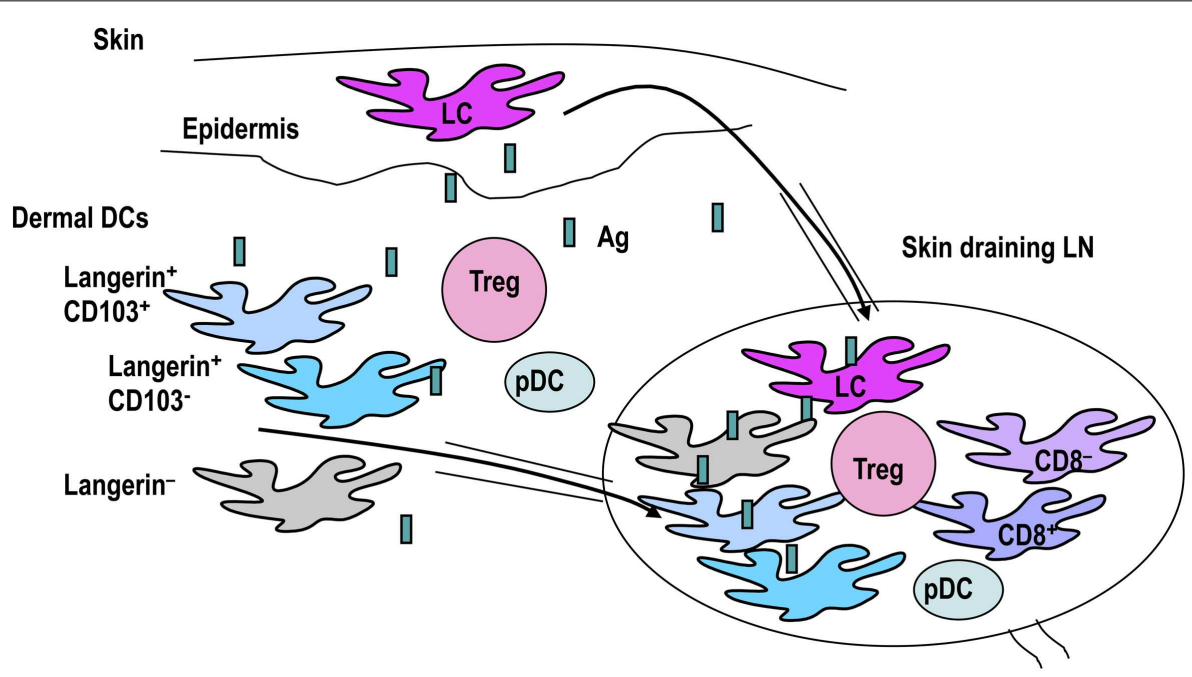

FIGURE 2 |The classification of skin DC subsets. Skin DCs are epidermal Langerhans cells (LCs) and dermal DCs. Dermal DCs constitute Langerin ${ }^{+}$and Langerin- ${ }^{-}$subtypes. Langerin ${ }^{+}$dermal DCs are further subdivided into $\mathrm{CD}_{103}{ }^{+}$and $\mathrm{CD} 103^{-}$groups. These skin DCs carry antigens and migrate to draining lymph nodes. Skin-draining lymph nodes contain many DC subsets, including skin migratory DCs, resident classical CD8 ${ }^{+} \mathrm{DCs}, \mathrm{CD} 8^{-} \mathrm{DCs}$, and pDCs. Therefore, interactions between DC subsets and T-regs in skin and skin-draining lymph nodes may be complex. 
while $\mathrm{CD}_{103^{-}}$Langerin $^{+} \mathrm{CD}_{11 b^{\text {low }}}$ dermal DCs and Langerin ${ }^{-}$ DCs should be CD11b-type DCs. In brief, skin $\mathrm{CD}_{103^{+}}$dermal DC subsets are CD8-type DCs. Considering that intestine CD103 ${ }^{+}$ DCs induce Foxp $3^{+}$T-regs using RA, the issue of whether skin $\mathrm{CD}_{103^{+}}$DCs also activate RA and induce Foxp3 ${ }^{+}$T-regs was investigated by a couple of groups. Among the skin DC subsets investigated for ability to activate RA, dermal-derived CD103DCs, and not $\mathrm{CD}_{103^{+}}$DCs, produced RA and induce Foxp3 ${ }^{+}$ T-regs in the skin-draining LNs (Guilliams et al., 2010a). Similarly, migratory $\mathrm{CD} 11 \mathrm{c}^{+} \mathrm{MHC}$ classII ${ }^{\text {high }} \mathrm{DCs}$, which should contain both $\mathrm{CD}_{103}{ }^{+}$and $\mathrm{CD}_{103}{ }^{-}$DCs, induced Foxp3 ${ }^{+}$T-regs from Foxp ${ }^{-}$cells using RALDH (Vitali et al., 2012). Moreover, Langerin $^{+}$dermal DCs, containing $\mathrm{CD}_{103}{ }^{+}$and $\mathrm{CD}_{103^{-}}{ }^{-} \mathrm{DCs}$ (Henri et al., 2010), induced Foxp3 $3^{+}$T-regs in the OVA-expressing keratinocyte system (Azukizawa et al., 2011). Thus, it appears that migratory dermal DCs including both $\mathrm{CD}_{103}{ }^{+}$and $\mathrm{CD} 103^{-} \mathrm{DC}$ population play a role in inducing Foxp $3^{+}$T-regs from Foxp $3^{-} \mathrm{T}$ cells in skin (Table 2).

The next issue to resolve was the role of LCs in inducing Foxp $3^{+}$ T-regs. LCs produce TGF- $\beta$ (Kaplan et al., 2007; Bobr et al., 2012), and are suggested to function in maintaining tolerance rather than inducing immunity (Kaplan et al., 2005; Obhrai et al., 2008; Igyarto et al., 2009; Bobr et al., 2010; Fukunaga et al., 2010; Yoshiki et al., 2010; Kautz-Neu et al., 2011; Shklovskaya et al., 2011). Epidermal RANKL-stimulated LCs expand T-regs in transgenic mice with RANKL expression under the K14 promoter (Loser et al., 2006). Importantly, a recent study reported proliferation of human skin Foxp $3^{+}$T-regs with autologous LCs in the culture (Seneschal et al., 2012). However, in this report, it was unclear whether T-regs were expanded or induced from Foxp $3^{-}$T cells, since whole T cells were used as the starting population. It is a considerable challenge to distinguish between Natural T-reg expansion and Induced T-reg induction, because Foxp3 is easily up-regulated in humans (Walker et al., 2003; Tran et al., 2007), and it is impossible to use the Foxp3reporter as in mice. Another recent investigation showed that LCs protect against allergic contact dermatitis by toleralizing $\mathrm{CD} 8^{+} \mathrm{T}$ cells through Foxp $3^{+}$T-regs (Gomez de Aguero et al., 2012). In this study, the conversion of Foxp $3^{+}$T-regs from Foxp $3^{-}$cells did not occur, suggesting that LCs expand already existing Natural T-regs.

Finally, Langerin ${ }^{+}$DC-depleted mice lacking LCs and Langrin ${ }^{+}$ dermal DCs did not develop autoimmune diseases (Bennett et al.,

Table 2 | Skin DC subsets and probable mechanisms to induce Foxp3 ${ }^{+}$ T-regs.

\begin{tabular}{|c|c|c|}
\hline Skin DC subsets & & Reference \\
\hline LCs & TGF- $\beta$ production & $\begin{array}{l}\text { Kaplan et al. (2007), } \\
\text { Bobr et al. (2012) }\end{array}$ \\
\hline $\begin{array}{l}\text { Langerin- }{ }^{-} \text {CD103- }{ }^{-} \text {CD11 } b^{+} \\
\text {dermal DCs }\end{array}$ & $\mathrm{RALDH}^{+}$ & $\begin{array}{l}\text { Guilliams et al. } \\
\text { (2010a) }\end{array}$ \\
\hline $\begin{array}{l}\text { MHC class II }{ }^{\text {high }} \mathrm{CD} 11 \mathrm{c}^{+} \\
\text {migratory DCs }\left(\mathrm{CD}_{103^{ \pm}}\right)\end{array}$ & $\mathrm{RALDH}^{+}$ & Vitali et al. (2012) \\
\hline Langerin ${ }^{+}$dermal DCs $\left(\mathrm{CD}_{103}{ }^{ \pm}\right)$ & TGF- $\beta$ production & $\begin{array}{l}\text { Azukizawa et al. } \\
\text { (2011) }\end{array}$ \\
\hline
\end{tabular}

2005; Kaplan et al., 2005; Kissenpfennig et al., 2005), suggesting that other types of DCs compensate to maintain the Foxp $3^{+}$T-reg population.

\section{POSSIBLE ROLE OF TLR-2 SIGNALING IN INDUCING FOXP3+ T-REGS IN SKIN}

As discussed above, skin DCs appear to play a key role in expanding Natural T-regs and inducing T-regs. It is speculated that Foxp $3^{+}$ T-regs also function in maintaining the tolerance versus immunity in the skin (Dudda et al., 2008; Tomura et al., 2010; Naik et al., 2012). Indeed, Foxp $3^{+}$T-regs are enriched in skin, compared to lymphoid tissue (Sather et al., 2007; Naik et al., 2012). It would therefore be interesting to determine the type of signals controlling Foxp $3^{+}$T-regs in skin. One possibility is TLR signals, since skin is exposed to many commensals, among which yeast, Staphylococcus and Mycoplasma provide a source of TLR-2 ligands (Yamazaki et al., 2011). TLR-2 signaling is known to activate Foxp3 ${ }^{+}$T-reg induction (Chen et al., 2009; Manicassamy et al., 2009; Round and Mazmanian, 2010). Zymosan from yeast can bind to TLR-2 and dectin-1, a C-type lectin, expressed on DCs, and induces TGF- $\beta$ (Dillon et al., 2006). Zymosan induces RALDH expression in DCs via a mechanism largely dependent on TLR2-mediated activation, which induces Foxp3 ${ }^{+}$T-regs (Manicassamy et al., 2009). Pam2 lipopeptides, derived from Staphylococcus aureus or Mycoplasma, are TLR-2 ligands (Yamazaki et al., 2011). Therefore, stimulation from yeast, Staphylococcus or Mycoplasma may be a trigger for the induction of Foxp $3^{+}$T-regs through TLR-2.

TLR-2 signal induces Foxp $3^{+}$T-regs via IL-10 production and suppresses anti-tumor response to melanoma in mice (Yamazaki et al., 2011). Other studies have consistently reported that DCs activated by TLR-2 express RALDH and induce Foxp3 (Manicassamy et al., 2009). It is unclear whether TLR-2 signals stimulate induction of Foxp $3^{+}$T-regs from Foxp3 $3^{-}$precursor cells or expansion of Natural T-regs, since most investigators used whole CD4 ${ }^{+}$ $\mathrm{T}$ cells as starting population. TLR-2 induces RALHD in DCs. Therefore, it is speculated that TLR-2 signals induce Foxp $3^{+}$T-regs from Foxp $3^{-}$precursor cells as $\mathrm{CD}_{103}{ }^{+} \mathrm{DCs}$ from the intestine.

TLR-2 stimulation through commensals may additionally be required for Foxp3 induction, especially in the skin where yeast, Staphylococcus, or Mycoplasma always exist. However, a significant finding by the group of Belkaid is that the frequency of Foxp $3^{+}$T-regs in skin is more increased in germ-free mice (Naik et al., 2012). In cases where a skin commensal bacteria, S. epidermidis, was applied on the skin of germ-free mice, Foxp $3^{+}$T-regs were reduced and IFN- $\gamma$ producing effector $\mathrm{T}$ cells increased in skin (Naik et al., 2012). The resident commensals in skin appear to modulate the induction of effector $\mathrm{T}$ cells in a Myd88/IL-1dependent manner (Naik et al., 2012). Moreover, keratinocytes from germ-free mice actively produce IL-1 receptor antagonist (IL$1 \mathrm{ra}$ ), leading to the suppression of effector T-cell development, and DC populations are not affected in skin (Naik et al., 2012). Thus, it appears that Foxp $3^{+}$T-reg and effector T cell balance is controlled directly by commensals in skin. Surprisingly, only a single type of commensal is sufficient to induce effector $\mathrm{T}$ cells and conversely reduce Foxp $3^{+}$T-regs in skin. Further studies are required to clarify whether TLR-2 signaling is required for maintaining Foxp $3^{+}$ T-regs in skin. 


\section{DCs HAVE A ROLE IN INDUCING OR EXPANDING FOXP3+ T-REGS IN THE ORAL CAVITY}

We recently focused on the oral-cavity located between the skin and intestine, which also contains many commensals. The oral cavity is often affected by systemic immunological disorders, such as Stevens-Johnson syndrome and Behçet disease, and exposed to several antigens, including foods and pathogens, and mechanical signals via biting. Antigen administration through the oral cavity, such as sublingual (s.l.) immunotherapy, is employed to treat respiratory allergy and allergic rhinitis and conjunctivitis (Moingeon and Mascarell, 2012; Passalacqua et al., 2013). However, the mechanisms by which tolerance versus immunity are regulated in the oral cavity are unclear at present.

Dendritic cells from the oral cavity are capable of generating Foxp $3^{+}$T-regs, which may maintain tolerance (Figure 3) (Yamazaki et al., 2012). CD11c ${ }^{+}$DCs from oral-cavity-draining lymph nodes have the capacity to generate Foxp $3^{+}$T-regs in the presence of antigen in vitro (Yamazaki et al., 2012). It is possible that specialized DC subsets are required to induce Foxp $3^{+}$T-regs in the oral cavity, as $\mathrm{CD} 103^{+} \mathrm{DCs}$ induce Foxp $3^{+}$T-regs in the intestine. No increase in migratory class $\mathrm{II}^{\text {high }} \mathrm{DCs}, \mathrm{CD}_{103}{ }^{+} \mathrm{DCs}$, $\mathrm{CD}^{+}$DCs, and pDCs in the oral-cavity-draining lymph nodes was observed (Yamazaki et al., 2012). The frequency of CD8 ${ }^{-}$DCs in oral-cavity-draining lymph nodes was slightly higher than in axillary lymph nodes (Yamazaki et al., 2012). In view of our former

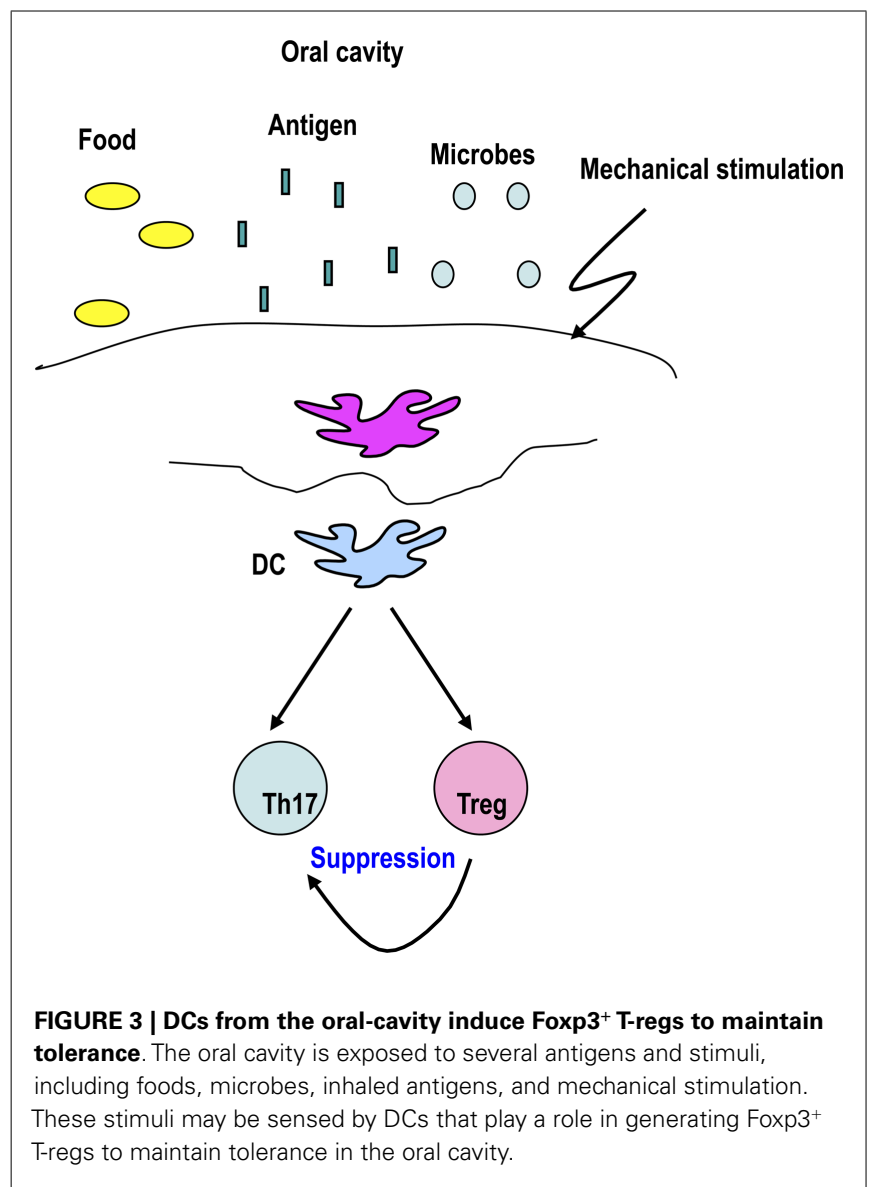

finding that $33 \mathrm{D} 1^{+} \mathrm{CD} 8^{-}$DCs expand Natural T-regs (Dudziak et al., 2007), it is possible that CD8 ${ }^{-}$DCs play a role in expanding Natural T-regs, rather than inducing Foxp $3^{+}$T-regs from Foxp3 ${ }^{-}$ precursors in oral-cavity-draining lymph nodes.

Three distinct subsets of migrating DCs from the oral mucosa have been identified in the regional lymph nodes (Chalermsarp and Azuma, 2009), specifically, CD11 chigh

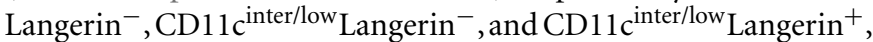
which are all $\mathrm{CD} 8$ negative. It appears that $\mathrm{CD} 11 \mathrm{c}^{+} \mathrm{CD} 8^{-} \mathrm{DCs}$ capture s.l. administered antigen and ferries it into the draining lymph nodes where both migratory $\mathrm{CD} 8^{-} \mathrm{DCs}$ and resident CD $8^{+}$DCs prime the CD4 response (Song et al., 2009). S.1.administered protein antigens are captured by DCs and are rapidly recruited to draining lymph nodes within $12-24 \mathrm{~h}$, and the regulatory mechanisms established within 2-5 days in draining lymph nodes (Passalacqua et al., 2013). Both Foxp $3^{+}$T-regs and IL-10 producing Tr1 type T-regs are induced upon s.l. immunization (Bohle et al., 2007).

Further research is required to establish whether DCs in oralcavity-draining lymph nodes induce Foxp $3^{+}$T-regs from Foxp $3^{-}$ precursors or expand existing Foxp $3^{+}$T-regs. Additionally, the mechanisms underlying the maintenance of immune tolerance in the oral-cavity require clarification.

\section{FOXP3 ${ }^{+}$T-REGS AND DC SUBSETS IN HUMANS}

The majority of studies on Foxp3 ${ }^{+}$T-regs and DCs described above were performed using mice. It is quite important to ascertain whether the interactions of Foxp $3^{+}$T-regs and DCs are similar in mice and humans. As we mentioned earlier, a limited number of studies have been performed in humans showing that epidermal LCs stimulate the proliferation of Foxp $3^{+}$T-regs in the culture (Seneschal et al., 2012) and IL-10 producing T-reg is induced by ASGPR DCs in human (Li et al., 2012).

Murine $\mathrm{CD} 8^{+} \mathrm{DEC} 205^{+} \mathrm{DCs}$ are specialized DCs to induce Foxp3 ${ }^{+}$T-regs from Foxp3 ${ }^{-} \mathrm{T}$ cells (Yamazaki et al., 2008), but the applicability of these results to humans requires further study. Four groups simultaneously identified BDCA3(CD141) $)^{+}$DCs as the human equivalent of mouse $\mathrm{CD} 8^{+} \mathrm{DCs}$ (Bachem et al., 2010; Crozat et al., 2010; Jongbloed et al., 2010; Poulin et al., 2010). In terms of similarities, murine $\mathrm{CD}^{+}$DCs and human $\mathrm{BDCA}^{+}{ }^{+}$DCs express XCR1, a chemokine receptor (Dorner et al., 2009; Bachem et al., 2010; Crozat et al., 2010, 2011; Kroczek and Henn, 2012). Moreover, both murine $\mathrm{CD}^{+}$DCs and human $\mathrm{BDCA} 3^{+} \mathrm{XCR} 1^{+} \mathrm{DCs}$ are specialized DCs for cross presentation (Dudziak et al., 2007; Dorner et al., 2009; Jongbloed et al., 2010; Poulin et al., 2010; Bachem et al., 2012). Murine $\mathrm{CD}^{+}$DCs are tolerogenic DCs in mice (Hawiger et al., 2001; Bonifaz et al., 2002; Mahnke et al., 2003; Kretschmer et al., 2005; Yamazaki et al., 2008). A recent study demonstrated that $\mathrm{BDCA}^{+} \mathrm{DCs}$ in skin induce IL-10 and regulatory $\mathrm{T}$ cells in humans (Chu et al., 2012). BDCA $3^{+}$DCs and Foxp $3^{+}$T-regs are closely located within skin (Chu et al., 2012). Moreover, $\mathrm{BDCA}^{+}$DCs induce $\mathrm{CD} 25^{\text {high }} \mathrm{CD} 4^{+} \mathrm{T}$ cells that suppress the alloimmune response in vitro and in vivo (Chu et al., 2012). Therefore, it is possible that $\mathrm{BDCA} 3^{+}$DCs in humans have specialized function in inducing Foxp $3^{+}$T-regs, similar to $\mathrm{CD} 8^{+} \mathrm{DCs}$ in mice. 
Recent experiments showed that the function of Foxp $3^{+} \mathrm{T}$ regs is recovered in psoriatic patients after exposure to ultraviolet (UV) therapy (Furuhashi et al., 2013). Interestingly, Krueger and colleagues reported increased BDCA $3^{+}$DCs in skin biopsy specimens after narrow band UV therapy (Kennedy Crispin et al., 2013), suggesting that $\mathrm{BDCA}^{+}$DCs play a key role in Foxp $3^{+}$T-reg function following UV therapy. Further studies are required to examine human DC and T-reg interactions.

\section{CONCLUSION}

We have discussed the roles of DCs in inducing and expanding Foxp $3^{+}$T-regs. Induction or expansion of antigen-specific T-regs using DCs may be provide an effective solution to treat

\section{REFERENCES}

Abbas, A. K., Benoist, C., Bluestone, J. A., Campbell, D. J., Ghosh, S., Hori, S., et al. (2013). Regulatory T cells: recommendations to simplify the nomenclature. Nat. Immunol. 14, 307-308. doi:10.1038/ni.2554

Akimova, T., Beier, U. H., Wang, L., Levine, M. H., and Hancock, W. W. (2011). Helios expression is a marker of $\mathrm{T}$ cell activation and proliferation. PLOS ONE 6:e24226. doi:10.1371/journal.pone.0024226

Asano, M., Toda, M., Sakaguchi, N., and Sakaguchi, S. (1996). Autoimmune disease as a consequence of developmental abnormality of a $\mathrm{T}$ cell subpopulation. J. Exp. Med. 184, 387-396. doi:10.1084/jem.184.2.387

Atarashi, K., Tanoue, T., Shima, T., Imaoka, A., Kuwahara, T., Momose, Y., et al. (2011). Induction of colonic regulatory $\mathrm{T}$ cells by indigenous Clostridium species. Science 331, 337-341. doi:10.1126/science.1198469

Azukizawa, H., Dohler, A., Kanazawa, N., Nayak, A., Lipp, M., Malissen, B., et al. (2011). Steady state migratory RelB+ langerin+ dermal dendritic cells mediate peripheral induction of antigen-specific CD4+ CD25+ Foxp3+ regulatory T cells. Eur. J. Immunol. 41, 1420-1434. doi:10.1002/eji.201040930

Bachem, A., Guttler, S., Hartung, E., Ebstein, F., Schaefer, M., Tannert, A., et al. (2010). Superior antigen cross-presentation and XCR1 expression define human CD11c+CD141+ cells as homologues of mouse CD8+ dendritic cells. J. Exp. Med. 207, 1273-1281. doi:10.1084/jem.20100348

Bachem, A., Hartung, E., Guttler, S., Mora, A., Zhou, X., Hegemann, A., et al. (2012). Expression of XCR1 characterizes the Batf3-dependent lineage of dendritic cells capable of antigen crosspresentation. Front. Immunol. 3:214. doi:10.3389/fimmu.2012.00214
Baeke, F., Takiishi, T., Korf, H., Gysemans, C., and Mathieu, C. (2010). Vitamin D: modulator of the immune system. Curr. Opin. Pharmacol. 10, 482-496. doi:10.1016/j.coph.2010.04.001

Bayer, A. L., Yu, A., Adeegbe, D., tial role for interleukin-2 for CD4(+)CD25(+) $\mathrm{T}$ regulatory cell development during the neonatal period. J. Exp. Med. 201, 769-777. doi:10.1084/jem.20041179

Bedoui, S., Whitney, P. G., Waithman, J., Eidsmo, L., Wakim, L., Caminschi, I., et al. (2009). Crosspresentation of viral and self antigens by skin-derived CD103+ dendritic cells. Nat. Immunol. 10, 488-495. doi:10.1038/ni.1724

Belz, G. T., and Nutt, S. L. (2012). Transcriptional programming of the dendritic cell network. Nat. Rev. Immunol. 12, 101-113. doi:10.1038/nri3149

Bennett, C. L., Van Rijn, E., Jung, S., Inaba, K., Steinman, R. M., Kapsenberg, M. L., et al. (2005). Inducible ablation of mouse Langerhans cells diminishes but fails to abrogate contact hypersensitivity. J. Cell Biol. 169, 569-576. doi:10.1083/jcb.200501071

Birnberg, T., Bar-On, L., Sapoznikov, A., Caton, M. L., Cervantes-Barragan, L., Makia, D., et al. (2008). Lack of conventional dendritic cells is compatible with normal development and $\mathrm{T}$ cell homeostasis, but causes myeloid proliferative syndrome. Immunity 29, 986-997. doi:10.1016/j.immuni.2008.10.012

Bobr, A., Igyarto, B. Z., Haley, K. M., Li, M. O., Flavell, R. A., and Kaplan, D. H. (2012). Autocrine/paracrine TGF-betal inhibits Langerhans cell migration. Proc. Natl. Acad. Sci. U.S.A. 109, 10492-10497. doi:10.1073/pnas.1119178109

Bobr, A., Olvera-Gomez, I., Igyarto, B. Z., Haley, K. M., Hogquist, K. A., and Kaplan, D. H. (2010). and Malek, T. R. (2005). Essen-

autoimmune diseases, transplantation tolerance, and allergy. Further studies focusing on polyclonal $\mathrm{T}$ cell repertoires to generate antigen-specific Foxp $3^{+}$T-regs are warranted, particularly in humans.

\section{ACKNOWLEDGMENTS}

We are grateful to Dr. Ralph M. Steinman for encouraging Sayuri Yamazaki to continue research. This work was funded by a Grant-in-Aid for challenging Exploratory Research, a Grant-inAid for Scientific Research B from Japan Society for the Promotion of Science, the Mochida Memorial Foundation for Medical and Pharmaceutical Research, and Aichi Cancer Research Foundation.

Acute ablation of Langerhans cells enhances skin immune responses. J. Immunol. 185, 4724-4728. doi:10.4049/jimmunol.1001802

Bohle, B., Kinaciyan, T., Gerstmayr, M., Radakovics, A., Jahn-Schmid, B., and Ebner, C. (2007). Sublingual immunotherapy induces IL-10-producing $\mathrm{T}$ regulatory cells, allergen-specific T-cell tolerance, and immune deviation. J. Allergy Clin. Immunol. 120, 707-713. doi:10.1016/j.jaci.2007.06.013

Bonifaz, L., Bonnyay, D., Mahnke, K., Rivera, M., Nussenzweig, M. C., and Steinman, R. M. (2002). Efficient targeting of protein antigen to the dendritic cell receptor DEC-205 in the steady state leads to antigen presentation on major histocompatibility complex class I products and peripheral CD8 $+\mathrm{T}$ cell tolerance. J. Exp. Med. 196, 1627-1638. doi:10.1084/jem.20021598

Bursch, L. S., Wang, L., Igyarto, B., Kissenpfennig, A., Malissen, B., Kaplan, D. H., et al. (2007). Identification of a novel population of Langerin+ dendritic cells. J. Exp. Med. 204, 3147-3156. doi:10.1084/jem.20071966

Caux, C., Dezutter-Dambuyant, C., Schmitt, D., and Banchereau, J. (1992). GM-CSF and TNF-alpha cooperate in the generation of dendritic Langerhans cells. Nature 360, 258-261. doi:10.1038/3602 $58 \mathrm{a} 0$

Chalermsarp, N., and Azuma, M. (2009). Identification of three distinct subsets of migrating dendritic cells from oral mucosa within the regional lymph nodes. Immunology 127, 558-566. doi:10.1111/j.13652567.2008.03031.x

Chen, Q., Davidson, T. S., Huter, E. N., and Shevach, E. M. (2009). Engagement of TLR2 does not reverse the suppressor function of mouse regulatory T cells, but promotes their survival. J. Immunol. 183, 4458-4466. doi:10.4049/jimmunol.0901465
Chen, W., Jin, W., Hardegen, N., Lei, K. J., Li, L., Marinos, N., et al. (2003). Conversion of peripheral CD4+CD25- naive $\mathrm{T}$ cells to $\mathrm{CD} 4+\mathrm{CD} 25+$ regulatory $\mathrm{T}$ cells by TGF-beta induction of transcription factor Foxp3. J. Exp. Med. 198, 1875-1886. doi:10.1084/jem.20030152

Cheong, C., Idoyaga, J., Do, Y., Pack, M., Park, S. H., Lee, H., et al. (2007). Production of monoclonal antibodies that recognize the extracellular domain of mouse langerin/CD207. J. Immunol. Methods 324, 48-62. doi:10.1016/j.jim.2007.05.001

Cheong, C., Matos, I., Choi, J. H., Dandamudi, D. B., Shrestha, E., Longhi, M. P., et al. (2010). Microbial stimulation fully differentiates monocytes to DC-SIGN/CD209(+) dendritic cells for immune $\mathrm{T}$ cell areas. Cell 143, 416-429. doi:10.1016/j.cell.2010.09.039

Chu, C. C., Ali, N., Karagiannis, P., Di Meglio, P., Skowera, A., Napolitano, L., et al. (2012). Resident CD141 (BDCA3)+ dendritic cells in human skin produce IL-10 and induce regulatory $\mathrm{T}$ cells that suppress skin inflammation. J. Exp. Med. 209, 935-945. doi:10.1084/jem.2011 2583

Coombes, J. L., Siddiqui, K. R., Arancibia-Carcamo, C. V., Hall, J., Sun, C. M., Belkaid, Y., et al. (2007). A functionally specialized population of mucosal CD103+ DCs induces Foxp3+ regulatory $\mathrm{T}$ cells via a TGF-beta and retinoic acid-dependent mechanism. J. Exp. Med. 204, 1757-1764. doi:10.1084/jem.20070590

Crozat, K., Guiton, R., Contreras, V., Feuillet, V., Dutertre, C. A., Ventre, E., et al. (2010). The XC chemokine receptor 1 is a conserved selective marker of mammalian cells homologous to mouse CD8alpha+ dendritic cells. J. Exp. Med. 207, 1283-1292. doi:10.1084/jem.2010 0223 
Crozat, K., Tamoutounour, S., Vu Manh, T. P., Fossum, E., Luche, H., Ardouin, L., et al. (2011). Cutting edge: expression of XCR1 defines mouse lymphoid-tissue resident and migratory dendritic cells of the CD8alpha+ type. J. Immunol. 187, 4411-4415. doi:10.4049/jimmunol.1101717

Darrasse-Jeze, G., Deroubaix, S., Mouquet, H., Victora, G. D., Eisenreich, T., Yao, K. H., et al. (2009). Feedback control of regulatory $\mathrm{T}$ cell homeostasis by dendritic cells in vivo. J. Exp. Med. 206, 1853-1862. doi:10.1084/jem.20090746

Davidson, T. S., Dipaolo, R. J., Andersson, J., and Shevach, E. M. (2007). Cutting Edge: IL-2 is essential for TGF-beta-mediated induction of Foxp3 $+\mathrm{T}$ regulatory cells. J. Immunol. 178, 4022-4026.

Dillon, S., Agrawal, S., Banerjee, K., Letterio, J., Denning, T. L., Oswald-Richter, K., et al. (2006). Yeast zymosan, a stimulus for TLR2 and dectin-1, induces regulatory antigen-presenting cells and immunological tolerance. J. Clin. Invest. 116, 916-928. doi:10.1172/JCI27203

Dorner, B. G., Dorner, M. B., Zhou, X., Opitz, C., Mora, A., Guttler, S., et al. (2009). Selective expression of the chemokine receptor XCR1 on cross-presenting dendritic cells determines cooperation with CD8+ $\mathrm{T}$ cells. Immunity 31, 823-833. doi:10.1016/j.immuni

Dudda, J. C., Perdue, N., Bachtanian, E., and Campbell, D. J. (2008). Foxp3+ regulatory $\mathrm{T}$ cells maintain immune homeostasis in the skin. J. Exp. Med. 205, 1559-1565. doi:10.1084/jem.20072594

Dudziak, D., Kamphorst, A. O., Heidkamp, G. F., Buchholz, V. R., Trumpfheller, C., Yamazaki, S., et al. (2007). Differential antigen processing by dendritic cell subsets in vivo. Science 315, 107-111. doi:10.1126/science. 1136080

Edelson, B. T., Kc, W., Juang, R., Kohyama, M., Benoit, L. A., Klekotka, P. A., et al. (2010). Peripheral CD103+ dendritic cells form a unified subset developmentally related to CD8alpha + conventional dendritic cells. J. Exp. Med. 207, 823-836. doi:10.1084/jem.20091627

Fehervari, Z., and Sakaguchi, S. (2004). Control of Foxp3+ CD25+CD4+ regulatory cell activation and function by dendritic cells. Int. Immunol. 16, 1769-1780. doi:10.1093/intimm/dxh178

Fontenot, J. D., Gavin, M. A., and Rudensky, A. Y. (2003). Foxp3 programs the development and function of $\mathrm{CD} 4+\mathrm{CD} 25+$ regulatory $\mathrm{T}$ cells. Nat. Immunol. 4, 330-336. doi:10.1038/ni904

Fritsche, J., Mondal, K., Ehrnsperger, A., Andreesen, R., and Kreutz, M. (2003). Regulation of 25-hydroxyvitamin D3-1 alphahydroxylase and production of 1 alpha, 25-dihydroxyvitamin D3 by human dendritic cells. Blood 102, 3314-3316. doi:10.1182/blood-2002-11-3521

Fukaya, T., Murakami, R., Takagi, H., Sato, K., Sato, Y., Otsuka, H., et al. (2012). Conditional ablation of CD205+ conventional dendritic cells impacts the regulation of T-cell immunity and homeostasis in vivo. Proc. Natl. Acad. Sci. U.S.A. 109, 11288-11293. doi:10.1073/pnas.1202208109

Fukunaga, A., Khaskhely, N. M., Ma, Y., Sreevidya, C. S., Taguchi, K., Nishigori, C., et al. (2010). Langerhans cells serve as immunoregulatory cells by activating NKT cells. J. Immunol. 185, 4633-4640. doi:10.4049/jimmunol.1000246

Furuhashi, T., Saito, C., Torii, K., Nishida, E., Yamazaki, S., and Morita, A. (2013). Photo(chemo)therapy reduces circulating Th17 cells and restores circulating regulatory $\mathrm{T}$ cells in psoriasis. PLoS ONE 8:e54895. doi:10.1371/journal.pone.0054895

Gaudreau, S., Guindi, C., Menard, M., Besin, G., Dupuis, G., and Amrani, A. (2007). Granulocyte-macrophage colony-stimulating factor prevents diabetes development in NOD mice by inducing tolerogenic dendritic cells that sustain the suppressive function of $\mathrm{CD} 4+\mathrm{CD} 25+$ regulatory $\mathrm{T}$ cells. J. Immunol. 179, 3638-3647.

Ghoreishi, M., Bach, P., Obst, J., Komba, M., Fleet, J. C., and Dutz, J. P. (2009). Expansion of antigen-specific regulatory $\mathrm{T}$ cells with the topical vitamin D analog calcipotriol. J. Immunol. 182, 6071-6078. doi:10.4049/jimmunol.0804064

Ginhoux, F., Collin, M. P., Bogunovic, M., Abel, M., Leboeuf, M., Helft, J., et al. (2007). Blood-derived dermal langerin+ dendritic cells survey the skin in the steady state. J. Exp. Med. 204, 3133-3146. doi:10.1084/jem.20071733

Ginhoux, F., Liu, K., Helft, J., Bogunovic, M., Greter, M., Hashimoto, D., et al. (2009). The origin and development of nonlymphoid tissue CD103+ DCs. J. Exp. Med. 206, 3115-3130. doi:10.1084/jem.20091756

Gomez de Aguero, M., Vocanson, M., Hacini-Rachinel, F., Taillardet, M.,
Sparwasser, T., Kissenpfennig, A., et al. (2012). Langerhans cells protect from allergic contact dermatitis in mice by tolerizing CD8(+) $\mathrm{T}$ cells and activating Foxp3(+) regulatory T cells. J. Clin. Invest. 122 , 1700-1711. doi:10.1172/JCI59725

Gottschalk, R. A., Corse, E., and Allison, J. P. (2010). TCR ligand density and affinity determine peripheral induction of Foxp3 in vivo. J. Exp. Med. 207, 1701-1711. doi:10.1084/jem.20091999

Gottschalk, R. A., Corse, E., and Allison, J. P. (2012). Expression of Helios in peripherally induced Foxp3+ regulatory $\mathrm{T}$ cells. J. Immunol. 188, 976-980. doi:10.4049/jimmunol.1102964

Granucci, F., Vizzardelli, C., Pavelka, N., Feau, S., Persico, M., Virzi, E. et al. (2001). Inducible IL-2 production by dendritic cells revealed by global gene expression analysis. Nat. Immunol. 2, 882-888. doi:10.1038/ni0901-882

Guilliams, M., Crozat, K., Henri, S. Tamoutounour, S., Grenot, P., Devilard, E., et al. (2010a). Skin-draining lymph nodes contain dermisderived $\mathrm{CD} 103(-)$ dendritic cells that constitutively produce retinoic acid and induce Foxp3(+) regulatory T cells. Blood 115, 1958-1968. doi:10.1182/blood-2009-09-24 5274

Guilliams, M., Henri, S., Tamoutounour, S., Ardouin, L., Schwartz-Cornil, I., Dalod, M., et al. (2010b). From skin dendritic cells to a simplified classification of human and mouse dendritic cell subsets. Eur. J. Immunol. 40, 2089-2094. doi:10.1002/eji.201040498

Hashimoto, D., Miller, J., and Merad, M. (2011). Dendritic cell and macrophage heterogeneity in vivo. Immunity 35, 323-335 doi:10.1016/j.immuni.2011.09.007

Hawiger, D., Inaba, K., Dorsett, Y., Guo, M., Mahnke, K., Rivera, M. et al. (2001). Dendritic cells induce peripheral $\mathrm{T}$ cell unresponsiveness under steady state conditions in vivo. J. Exp. Med. 194, 769-779. doi:10.1084/jem.194.6.769

Hawiger, D., Masilamani, R. F., Bettelli, E., Kuchroo, V. K., and Nussenzweig, M. C. (2004). Immunological unresponsiveness characterized by increased expression of CD5 on peripheral $\mathrm{T}$ cells induced by dendritic cells in vivo. Immunity 20, 695-705. doi:10.1016/j.immuni.2004.05.002

Heath, W. R., and Carbone, F. R. (2009). Dendritic cell subsets in primary and secondary $\mathrm{T}$ cell responses at body surfaces. Nat. Immunol. 10, 1237-1244. doi:10.1038/ni.1822

Henri, S., Poulin, L. F., Tamoutounour, S., Ardouin, L., Guilliams, M., De Bovis, B., et al. (2010). CD207+CD103+ dermal dendritic cells cross-present keratinocytederived antigens irrespective of the presence of Langerhans cells. J. Exp. Med. 207, 189-206. doi:10.1084/jem.20091964

Hill, J. A., Hall, J. A., Sun, C. M., Cai, Q., Ghyselinck, N., Chambon, P., et al. (2008). Retinoic acid enhances Foxp3 induction indirectly by relieving inhibition from CD4+CD44hi Cells. Immunity 29, 758-770. doi:10.1016/j.immuni.2008.09.018

Hori, S., Nomura, T., and Sakaguchi, S. (2003). Control of regulatory $\mathrm{T}$ cell development by the transcription factor Foxp3. Science 299, 1057-1061. doi:10.1126/science.1079490

Hsieh, C. S., Liang, Y., Tyznik, A. J., Self, S. G., Liggitt, D., and Rudensky, A. Y. (2004). Recognition of the peripheral self by naturally arising CD25+ CD4+ T cell receptors. Immunity 21, 267-277. doi:10.1016/j.immuni.2004.07.009

Hsieh, C. S., Zheng, Y., Liang, Y., Fontenot, J. D., and Rudensky, A. Y. (2006). An intersection between the self-reactive regulatory and nonregulatory $\mathrm{T}$ cell receptor repertoires. Nat. Immunol. 7, 401-410. doi:10.1038/ni1318

Huang, H., Dawicki, W., Zhang, X., Town, J., and Gordon, J. R (2010). Tolerogenic dendritic cells induce CD4+CD25hiFoxp3+ regulatory $\mathrm{T}$ cell differentiation from CD4+CD25-/loFoxp3- effector T cells. J. Immunol. 185, 5003-5010. doi:10.4049/jimmunol.0903446

Idoyaga, J., Fiorese, C., Zbytnuik, L., Lubkin, A., Miller, J., Malissen, B., et al. (2013). Specialized role of migratory dendritic cells in peripheral tolerance induction. J. Clin. Invest. 123, 844-854. doi:10.1172/JCI65260

Igyarto, B. Z., Jenison, M. C. Dudda, J. C., Roers, A., Muller, W., Koni, P. A., et al. (2009). Langerhans cells suppress contact hypersensitivity responses via cognate $\mathrm{CD} 4$ interaction and langerhans cell-derived IL-10. J. Immunol. 183, 5085-5093. doi:10.4049/jimmunol.0901884

Inaba, K., Inaba, M., Romani, N., Aya, H., Deguchi, M., Ikehara, S., et al. (1992). Generation of large numbers of dendritic cells from mouse bone marrow cultures supplemented with granulocyte/macrophage colony-stimulating factor. J. 
Exp. Med. 176, 1693-1702. doi:10.1084/jem.176.6.1693

Itoh, M., Takahashi, T., Sakaguchi, N., Kuniyasu, Y., Shimizu, J., Otsuka, F., et al. (1999). Thymus and autoimmunity: production of $\mathrm{CD} 25+\mathrm{CD} 4+$ naturally anergic and suppressive $\mathrm{T}$ cells as a key function of the thymus in maintaining immunologic self-tolerance. $J$. Immunol. 162, 5317-5326.

Iwata, M., Hirakiyama, A., Eshima, Y., Kagechika, H., Kato, C., and Song, S. Y. (2004). Retinoic acid imprints gut-homing specificity on $\mathrm{T}$ cells. Immunity 21, 527-538. doi:10.1016/j.immuni.2004.08.011

Jaensson, E., Uronen-Hansson, H., Pabst, O., Eksteen, B., Tian, J., Coombes, J. L., et al. (2008). Small intestinal CD103+ dendritic cells display unique functional properties that are conserved between mice and humans. J. Exp. Med. 205, 2139-2149. doi:10.1084/jem.20080414

Jeffery, L. E., Burke, F., Mura, M., Zheng, Y., Qureshi, O. S., Hewison, M., et al. (2009). 1,25Dihydroxyvitamin D3 and IL-2 combine to inhibit $\mathrm{T}$ cell production of inflammatory cytokines and promote development of regulatory $\mathrm{T}$ cells expressing CTLA- 4 and FoxP3. J. Immunol. 183, 5458-5467. doi:10.4049/jimmunol.0803217

Jongbloed, S. L., Kassianos, A. J., McDonald, K. J., Clark, G. J., Ju, X., Angel, C. E., et al. (2010). Human CD141+ (BDCA-3)+ dendritic cells (DCs) represent a unique myeloid DC subset that cross-presents necrotic cell antigens. J. Exp. Med. 207, 1247-1260. doi:10.1084/jem.20092140

Jordan, M. S., Boesteanu, A., Reed, A. J., Petrone, A. L., Holenbeck, A. E., Lerman, M. A., et al. (2001). Thymic selection of $\mathrm{CD} 4+\mathrm{CD} 25+$ regulatory $\mathrm{T}$ cells induced by an agonist self-peptide. Nat. Immunol. 2, 301-306. doi:10.1038/86302

Josefowicz, S. Z., Niec, R. E., Kim, H. Y., Treuting, P., Chinen, T., Zheng, Y., et al. (2012). Extrathymically generated regulatory $\mathrm{T}$ cells control mucosal TH2 inflammation. Nature 482, 395-399. doi:10.1038/nature10772

Kamphorst, A. O., Guermonprez, P., Dudziak, D., and Nussenzweig, M. C. (2010). Route of antigen uptake differentially impacts presentation by dendritic cells and activated monocytes. J. Immunol. 185, 3426-3435. doi:10.4049/jimmunol.1001205

Kaplan, D. H., Jenison, M. C., Saeland, S., Shlomchik, W. D., and
Shlomchik, M. J. (2005). Epidermal langerhans cell-deficient mice develop enhanced contact hypersensitivity. Immunity 23, 611-620. doi:10.1016/j.immuni.2005.10.008

Kaplan, D. H., Li, M. O., Jenison, M. C., Shlomchik, W. D., Flavell, R. A., and Shlomchik, M. J. (2007). Autocrine/paracrine TGFbetal is required for the development of epidermal Langerhans cells. J. Exp. Med. 204, 2545-2552. doi:10.1084/jem.20071401

Kautz-Neu, K., Noordegraaf, M., Dinges, S., Bennett, C. L., John, D., Clausen, B. E., et al. (2011). Langerhans cells are negative regulators of the anti-Leishmania response. J. Exp. Med. 208, 885-891. doi:10.1084/jem.20102318

Kennedy Crispin, M., Fuentes-Duculan, J., Gulati, N., Johnson-Huang, L. M., Lentini, T., Sullivan-Whalen, M., et al. (2013). Gene profiling of narrowband UVB-induced skin injury defines cellular and molecular innate immune responses. J. Invest. Dermatol. 133, 692-701. doi:10.1038/jid.2012.359

Khattri, R., Cox, T., Yasayko, S. A., and Ramsdell, F. (2003). An essential role for Scurfin in CD4+CD25+ $\mathrm{T}$ regulatory cells. Nat. Immunol. 4 , 337-342. doi:10.1038/ni909

Kim, J. M., Rasmussen, J. P., and Rudensky, A. Y. (2007). Regulatory T cells prevent catastrophic autoimmunity throughout the lifespan of mice. Nat. Immunol. 8, 191-197. doi:10.1038/ni1428

Kissenpfennig, A., Henri, S., Dubois, B., Laplace-Builhe, C., Perrin, P., Romani, N., et al. (2005). Dynamics and function of Langerhans cells in vivo: dermal dendritic cells colonize lymph node areas distinct from slower migrating Langerhans cells. Immunity 22, 643-654. doi:10.1016/j.immuni.2005.04.004

Kleinnijenhuis, J., Oosting, M., Joosten, L. A., Netea, M. G., and Van Crevel, R. (2011). Innate immune recognition of Mycobacterium tuberculosis. Clin. Dev. Immunol. 2011, 405310.

Kretschmer, K., Apostolou, I., Hawiger, D., Khazaie, K., Nussenzweig, M. C., and Von Boehmer, H. (2005). Inducing and expanding regulatory $\mathrm{T}$ cell populations by foreign antigen. Nat. Immunol. 6, 1219-1227. doi:10.1038/ni1265

Kroczek, R. A., and Henn, V. (2012). The role of XCR1 and its ligand XCL1 in antigen cross-presentation by murine and human dendritic cells. Front. Immunol. 3:14. doi:10.3389/fimmu.2012.00014
Li, D., Romain, G., Flamar, A. L., Duluc, D., Dullaers, M., Li, X. H., et al. (2012). Targeting selfand foreign antigens to dendritic cells via DC-ASGPR generates IL10-producing suppressive CD4+ T cells. J. Exp. Med. 209, 109-121. doi:10.1084/jem.20110399

Li, M. O., and Flavell, R. A. (2008). TGF-beta: a master of all $\mathrm{T}$ cell trades. Cell 134, 392-404. doi:10.1016/j.cell.2008.07.025

Liu, K., Victora, G. D., Schwickert, T. A., Guermonprez, P., Meredith, M. M., Yao, K., et al. (2009). In vivo analysis of dendritic cell development and homeostasis. Science 324, 392-397. doi:10.1126/science. 1170540

Loschko, J., Heink, S., Hackl, D., Dudziak, D., Reindl, W., Korn, T., et al. (2011). Antigen targeting to plasmacytoid dendritic cells via Siglec-H inhibits Th cell-dependent autoimmunity. J. Immunol. 187, 6346-6356. doi:10.4049/jimmunol.1102307

Loser, K., Mehling, A., Loeser, S., Apelt, J., Kuhn, A., Grabbe, S., et al. (2006). Epidermal RANKL controls regulatory T-cell numbers via activation of dendritic cells. Nat. Med. 12, 1372-1379. doi:10.1038/nm1518

Mahnke, K., Qian, Y., Knop, J., and Enk, A. H. (2003). Induction of $\mathrm{CD} 4+/ \mathrm{CD} 25+$ regulatory $\mathrm{T}$ cells by targeting of antigens to immature dendritic cells. Blood 101, 4862-4869. doi:10.1182/blood2002-10-3229

Malek, T. R., Yu, A., Vincek, V., Scibelli, P., and Kong, L. (2002). CD4 regulatory $\mathrm{T}$ cells prevent lethal autoimmunity in IL-2Rbeta-deficient mice. Implications for the nonredundant function of IL-2. Immunity 17, 167-178. doi:10.1016/S10747613(02)00367-9

Manicassamy, S., Ravindran, R., Deng, J., Oluoch, H., Denning, T. L., Kasturi, S. P., et al. (2009). Toll-like receptor 2-dependent induction of vitamin A-metabolizing enzymes in dendritic cells promotes $\mathrm{T}$ regulatory responses and inhibits autoimmunity. Nat. Med. 15, 401-409. doi:10.1038/nm.1925

Maraskovsky, E., Brasel, K., Teepe, M., Roux, E. R., Lyman, S. D., Shortman, K., et al. (1996). Dramatic increase in the numbers of functionally mature dendritic cells in Flt3 ligand-treated mice: multiple dendritic cell subpopulations identified. J. Exp. Med. 184, 1953-1962. doi:10.1084/jem.184.5.1953

Maruotti, N., and Cantatore, F. P. (2010). Vitamin D and the immune system. J. Rheumatol. 37, 491-495. doi:10.3899/jrheum.090797
Merad, M., Manz, M. G., Karsunky, H., Wagers, A., Peters, W., Charo, I., et al. (2002). Langerhans cells renew in the skin throughout life under steady-state conditions. Nat. Immunol. 3, 1135-1141. doi:10.1038/ni852

Milpied, P., Renand, A., Bruneau, J., Mendes-Da-Cruz, D. A., Jacquelin, S., Asnafi, V., et al. (2009). Neuropilin-1 is not a marker of human Foxp3+ Treg. Eur. J. Immunol. 39, 1466-1471. doi:10.1002/eji.200839040

Moingeon, P., and Mascarell, L. (2012). Induction of tolerance via the sublingual route: mechanisms and applications. Clin. Dev. Immunol. 2012, 623474. doi:10.1155/2012/623474

Mucida, D., Park, Y., Kim, G., Turovskaya, O., Scott, I., Kronenberg, M., et al. (2007). Reciprocal $\mathrm{TH} 17$ and regulatory $\mathrm{T}$ cell differentiation mediated by retinoic acid. Science 317, 256-260. doi:10.1126/science. 1145697

Nagao, K., Kobayashi, T., Moro, K., Ohyama, M., Adachi, T., Kitashima, D. Y., et al. (2012). Stress-induced production of chemokines by hair follicles regulates the trafficking of dendritic cells in skin. Nat. Immunol. 13, 744-752. doi:10.1038/ni.2353

Naik, S., Bouladoux, N., Wilhelm, C., Molloy, M. J., Salcedo, R., Kastenmuller, W., et al. (2012). Compartmentalized control of skin immunity by resident commensals. Science 337, 1115-1119. doi:10.1126/science. 1225152

Obhrai, J. S., Oberbarnscheidt, M., Zhang, N., Mueller, D. L., Shlomchik, W. D., Lakkis, F. G., et al. (2008) Langerhans cells are not required for efficient skin graft rejection. $J$. Invest. Dermatol. 128, 1950-1955. doi:10.1038/jid

Ohkura, N., Hamaguchi, M., Morikawa, H., Sugimura, K., Tanaka, A., Ito Y., et al. (2012). T cell receptor stimulation-induced epigenetic changes and Foxp3 expression are independent and complementary events required for Treg cell development. Immunity 37, 785-799. doi:10.1016/j.immuni.2012.09.010

Ohnmacht, C., Pullner, A., King, S. B., Drexler, I., Meier, S., Brocker, T., et al. (2009). Constitutive ablation of dendritic cells breaks selftolerance of CD4 T cells and results in spontaneous fatal autoimmunity. J. Exp. Med. 206, 549-559. doi:10.1084/jem.20082394

Passalacqua, G., Garelli, V., Sclifo, F., and Canonica, G. W. (2013). Sublingual immunotherapy for allergic rhinitis 
and conjunctivitis. Immunotherapy 5, 257-264. doi:10.2217/imt.12.157

Poulin, L. F., Henri, S., De Bovis, B., Devilard, E., Kissenpfennig, A., and Malissen, B. (2007). The dermis contains langerin + dendritic cells that develop and function independently of epidermal Langerhans cells. J. Exp. Med. 204, 3119-3131. doi:10.1084/jem.20071724

Poulin, L. F., Salio, M., Griessinger, E., Anjos-Afonso, F., Craciun, L., Chen, J. L., et al. (2010). Characterization of human DNGR-1+ BDCA3+ leukocytes as putative equivalents of mouse CD8alpha+ dendritic cells. J. Exp. Med. 207, 1261-1271. doi:10.1084/jem.20092618

Round, J. L., and Mazmanian, S. K. (2010). Inducible Foxp3+ regulatory T-cell development by a commensal bacterium of the intestinal microbiota. Proc. Natl. Acad. Sci. U.S.A. 107, 12204-12209. doi:10.1073/pnas.0909122107

Sakaguchi, S., Sakaguchi, N., Asano, M., Itoh, M., and Toda, M. (1995). Immunologic self-tolerance maintained by activated $\mathrm{T}$ cells expressing IL-2 receptor alpha-chains (CD25). Breakdown of a single mechanism of self-tolerance causes various autoimmune diseases. J. Immunol. 155, 1151-1164.

Sakaguchi, S., Yamaguchi, T., Nomura, T., and Ono, M. (2008). Regulatory $\mathrm{T}$ cells and immune tolerance. Cell 133, 775-787. doi:10.1016/j.cell.2008.05.009

Samstein, R. M., Josefowicz, S. Z., Arvey, A., Treuting, P. M., and Rudensky, A. Y. (2012). Extrathymic generation of regulatory $\mathrm{T}$ cells in placental mammals mitigates maternalfetal conflict. Cell 150, 29-38. doi:10.1016/j.cell.2012.05.031

Sather, B. D., Treuting, P., Perdue, N., Miazgowicz, M., Fontenot, J. D., Rudensky, A. Y., et al. (2007). Altering the distribution of Foxp3(+) regulatory $\mathrm{T}$ cells results in tissue-specific inflammatory disease. J. Exp. Med. 204, 1335-1347. doi:10.1084/jem.20070081

Seneschal, J., Clark, R. A., Gehad, A., Baecher-Allan, C. M., and Kupper, T. S. (2012). Human epidermal Langerhans cells maintain immune homeostasis in skin by activating skin resident regulatory $\mathrm{T}$ cells. Immunity 36, 873-884. doi:10.1016/j.immuni.2012. 03.018

Setoguchi, R., Hori, S., Takahashi, T., and Sakaguchi, S. (2005). Homeostatic maintenance of natural Foxp3(+) CD25(+) CD4(+) regulatory $\mathrm{T}$ cells by interleukin
(IL)-2 and induction of autoimmune disease by IL-2 neutralization. J. Exp. Med. 201, 723-735. doi:10.1084/jem.20041982

Shklovskaya, E., O'Sullivan, B. J., Ng, L. G., Roediger, B., Thomas, R., Weninger, W., et al. (2011). Langerhans cells are precommitted to immune tolerance induction. Proc. Natl. Acad. Sci. U.S.A. 108, 18049-18054. doi:10.1073/pnas.1110076108

Sigmundsdottir, H., and Butcher, E. C. (2008). Environmental cues, dendritic cells and the programming of tissue-selective lymphocyte trafficking. Nat. Immunol. 9, 981-987. doi:10.1038/ni.f.208

Sigmundsdottir, H., Pan, J., Debes, G. F., Alt, C., Habtezion, A., Soler, D., et al. (2007). DCs metabolize sunlightinduced vitamin D3 to 'program' $\mathrm{T}$ cell attraction to the epidermal chemokine CCL27. Nat. Immunol. 8 , 285-293. doi:10.1038/ni1433

Song, J. H., Kim, J. I., Kwon, H. J., Shim, D. H., Parajuli, N., Cuburu, N., et al. (2009). CCR7CCL19/CCL21-regulated dendritic cells are responsible for effectiveness of sublingual vaccination. J. Immunol. 182, 6851-6860. doi:10.4049/jimmunol.0803568

Steinman, R. M. (2012). Decisions about dendritic cells: past, present, and future. Annu. Rev. Immunol. 30, 1-22. doi:10.1146/annurevimmunol-100311-102839

Steinman, R. M., Hawiger, D., and Nussenzweig, M. C. (2003). Tolerogenic dendritic cells. Annu. Rev. Immunol. 21, 685-711. doi:10.1146/annurev.immunol.21. 120601.141040

Stern, J. N., Keskin, D. B., Kato, Z., Waldner, H., Schallenberg, S., Anderson, A., et al. (2010). Promoting tolerance to proteolipid proteininduced experimental autoimmune encephalomyelitis through targeting dendritic cells. Proc. Natl. Acad. Sci. U.S.A. 107, 17280-17285. doi:10.1073/pnas.1010263107

Sun, C. M., Hall, J. A., Blank, R. B., Bouladoux, N., Oukka, M., Mora, J. R., et al. (2007). Small intestine lamina propria dendritic cells promote de novo generation of Foxp3 $\mathrm{T}$ reg cells via retinoic acid. J. Exp. Med. 204, 1775-1785. doi:10.1084/jem.20070602

Swee, L. K., Bosco, N., Malissen, B., Ceredig, R., and Rolink, A. (2009). Expansion of peripheral naturally occurring $\mathrm{T}$ regulatory cells by Fms-like tyrosine kinase 3 ligand treatment. Blood 113, 6277-6287. doi:10.1182/blood-2008-06-161026
Takahashi, T., Kuniyasu, Y., Toda, M., Sakaguchi, N., Itoh, M., Iwata, M., et al. (1998). Immunologic self-tolerance maintained by CD25(CD4( naturally anergic and suppressive $\mathrm{T}$ cells: induction of autoimmune disease by breaking their anergic/suppressive state. Int. Immunol. 10, 1969-1980. doi:10.1093/intimm/10.12.1969

Tarbell, K. V., Yamazaki, S., Olson, K., Toy, P., and Steinman, R. M. (2004). CD25+ CD4+ T cells, expanded with dendritic cells presenting a single autoantigenic peptide, suppress autoimmune diabetes. J. Exp. Med. 199, 1467-1477. doi:10.1084/jem.20040180

Thornton, A. M., Korty, P. E., Tran, D. Q., Wohlfert, E. A., Murray, P. E., Belkaid, Y., et al. (2010). Expression of Helios, an Ikaros transcription factor family member, differentiates thymic-derived from peripherally induced Foxp $3+\mathrm{T}$ regulatory cells. J. Immunol. 184, 3433-3441. doi:10.4049/jimmunol.0904028

Thornton, A. M., and Shevach, E. M. (1998). CD4+CD25+ immunoregulatory $\mathrm{T}$ cells suppress polyclonal $\mathrm{T}$ cell activation in vitro by inhibiting interleukin 2 production. J. Exp. Med. 188, 287-296. doi:10.1084/jem.188.2.287

Tomura, M., Honda, T., Tanizaki, H., Otsuka, A., Egawa, G., Tokura, Y., et al. (2010). Activated regulatory $\mathrm{T}$ cells are the major $\mathrm{T}$ cell type emigrating from the skin during a cutaneous immune response in mice. J. Clin. Invest. 120, 883-893. doi:10.1172/JCI40926

Tran, D. Q., Ramsey, H., and Shevach, E. M. (2007). Induction of FOXP3 expression in naive human CD4+FOXP3 $\mathrm{T}$ cells by $\mathrm{T}$-cell receptor stimulation is transforming growth factor-beta dependent but does not confer a regulatory phenotype. Blood 110, 2983-2990. doi:10.1182/blood-2007-06-094656

Travis, M. A., Reizis, B., Melton, A. C., Masteller, E., Tang, Q., Proctor, J. M., et al. (2007). Loss of integrin alpha(v)beta8 on dendritic cells causes autoimmunity and colitis in mice. Nature 449, 361-365. doi:10.1038/nature 06110

Urry, Z., Chambers, E. S., Xystrakis, E., Dimeloe, S., Richards, D. F., Gabrysova, L., et al. (2012). The role of 1alpha,25-dihydroxyvitamin D3 and cytokines in the promotion of distinct Foxp3 (and IL-10+ CD4+ T cells. Eur. J. Immunol. 42, 2697-2708. doi:10.1002/eji.201242370

van de Laar, L., Coffer, P. J., and Woltman, A. M. (2012). Regulation of dendritic cell development by GMCSF: molecular control and implications for immune homeostasis and therapy. Blood 119, 3383-3393. doi:10.1182/blood-2011-11-370130

Verginis, P., Mclaughlin, K. A. Wucherpfennig, K. W., Von Boehmer, H., and Apostolou, I. (2008). Induction of antigenspecific regulatory $\mathrm{T}$ cells in wild-type mice: visualization and targets of suppression. Proc. Natl. Acad. Sci. U.S.A. 105, 3479-3484. doi:10.1073/pnas.0800149105

Vitali, C., Mingozzi, F., Broggi, A., Barresi, S., Zolezzi, F., Bayry, J., et al. (2012). Migratory, and not lymphoid-resident, dendritic cells maintain peripheral self-tolerance and prevent autoimmunity via induction of iTreg cells. Blood 120, 1237-1245. doi:10.1182/blood2011-09-379776

Walker, M. R., Kasprowicz, D. J., Gersuk, V. H., Benard, A., Van Landeghen, M., Buckner, J. H., et al. (2003). Induction of FoxP3 and acquisition of $\mathrm{T}$ regulatory activity by stimulated human CD4+CD25- T cells. J. Clin. Invest. 112, 1437-1443. doi:10.1172/JCI200319441

Waskow, C., Liu, K., Darrasse-Jeze, G., Guermonprez, P., Ginhoux, F. Merad, M., et al. (2008). The receptor tyrosine kinase Flt3 is required for dendritic cell development in peripheral lymphoid tissues. Nat. Immunol. 9, 676-683. doi:10.1038/ni.1615

Weiss, J. M., Bilate, A. M., Gobert, M., Ding, Y., Curotto De Lafaille, M. A. Parkhurst, C. N., et al. (2012). Neuropilin 1 is expressed on thymusderived natural regulatory $\mathrm{T}$ cells, but not mucosa-generated induced Foxp3+ T reg cells. J. Exp. Med. 209, S1721. doi:10.1084/jem.20120914

Yadav, M., Louvet, C., Davini, D., Gardner, J. M., Martinez-Llordella, M., Bailey-Bucktrout, S., et al. (2012). Neuropilin-1 distinguishes natural and inducible regulatory $\mathrm{T}$ cells among regulatory $\mathrm{T}$ cell subsets in vivo. J. Exp. Med. 209, S1711S1719. doi:10.1084/jem.20120822

Yamazaki, S., Bonito, A. J., Spisek, R., Dhodapkar, M., Inaba, K., and Steinman, R. M. (2007). Dendritic cells are specialized accessory cells along with TGF- for the differentiation of Foxp3 + CD4+ regulatory $\mathrm{T}$ cells from peripheral Foxp3 precursors. Blood 110, 4293-4302. doi:10.1182/blood-2007-05-088831

Yamazaki, S., Dudziak, D., Heidkamp, G. F., Fiorese, C., Bonito, A. J., Inaba, K., et al. (2008). CD8+ CD205+ splenic dendritic cells are specialized 
to induce Foxp3+ regulatory T cells. J. Immunol. 181, 6923-6933.

Yamazaki, S., Inaba, K., Tarbell, K. V., and Steinman, R. M. (2006a). Dendritic cells expand antigenspecific Foxp3+ CD25+ CD4+ regulatory $\mathrm{T}$ cells including suppressors of alloreactivity. Immunol. Rev. 212, 314-329. doi:10.1111/j.01052896.2006.00422.x

Yamazaki, S., Patel, M., Harper, A., Bonito, A., Fukuyama, H., Pack, M., et al. (2006b). Effective expansion of alloantigen-specific Foxp3+ $\mathrm{CD} 25+\mathrm{CD} 4+$ regulatory $\mathrm{T}$ cells by dendritic cells during the mixed leukocyte reaction. Proc. Natl. Acad. Sci. U.S.A. 103, 2758-2763. doi:10.1073/pnas.0510606103

Yamazaki, S., Iyoda, T., Tarbell, K., Olson, K., Velinzon, K., Inaba, K., et al. (2003). Direct expansion of functional $\mathrm{CD} 25+\mathrm{CD} 4+$ regulatory $\mathrm{T}$ cells by antigen-processing dendritic cells. J. Exp. Med. 198, 235-247. doi:10.1084/jem.20030422
Yamazaki, S., Maruyama, A., Okada, K., Matsumoto, M., Morita, A., and Seya, T. (2012). Dendritic cells from oral cavity induce Foxp3(+) regulatory $\mathrm{T}$ cells upon antigen stimulation. PLOS ONE 7:e51665. doi:10.1371/journal.pone.0051665

Yamazaki, S., Okada, K., Maruyama, A., Matsumoto, M., Yagita, H., and Seya, T. (2011). TLR2Dependent induction of IL-10 and Foxp3CD25CD4 regulatory $\mathrm{T}$ cells prevents effective anti-tumor immunity induced by Pam2 Lipopeptides in vivo. PLoS ONE 6:e18833. doi:10.1371/journal.pone.0018833

Yamazaki, S., and Steinman, R. M. (2009). Dendritic cells as controllers of antigen-specific Foxp3+ regulatory T cells. J. Dermatol. Sci. 54, 69-75. doi:10.1016/j.jdermsci

Yang, Y. C., Zhang, N., Van Crombruggen, K., Hu, G. H., Hong, S. L., and Bachert, C. (2012). Transforming growth factor-betal in inflammatory airway disease: a key for understanding inflammation and remodeling. Allergy 67, 1193-1202. doi:10.1111/j.13989995.2012.02880.x

Yoshiki, R., Kabashima, K., Sakabe, J., Sugita, K., Bito, T., Nakamura M., et al. (2010). The mandatory role of IL-10-producing and OX40 ligand-expressing mature Langerhans cells in local UVBinduced immunosuppression. J. Immunol. 184, 5670-5677. doi:10.4049/jimmunol.0903254

Zou, T., Caton, A. J., Koretzky, G. A. and Kambayashi, T. (2010). Dendritic cells induce regulatory $\mathrm{T}$ cell proliferation through antigendependent and -independent interactions. J. Immunol. 185, 2790-2799. doi:10.4049/jimmunol.0903740

Conflict of Interest Statement: The authors declare that the research was conducted in the absence of any commercial or financial relationships that could be construed as a potential conflict of interest.

Received: 30 April 2013; paper pending published: 15 May 2013; accepted: 04 June 2013; published online: 21 June 2013.

Citation: Yamazaki $S$ and Morita A (2013) Dendritic cells in the periphery control antigen-specific natural and induced regulatory $T$ cells. Front. Immunol. 4:151. doi 10.3389/fimmu.2013.00151

This article was submitted to Frontiers in Immunological Tolerance, a specialty of Frontiers in Immunology.

Copyright $(\odot) 2013$ Yamazaki and Morita. This is an open-access article distributed under the terms of the Creative Commons Attribution License, which permits use, distribution and reproduction in other forums, provided the original authors and source are credited and subject to any copyright notices concerning any third-party graphics etc. 